\title{
Comparative lipidomic analysis of Chlorella stigmatophora and Hemiselmis cf. andersenii in response to nitrogen-induced changes
}

\author{
Tomásia Fernandes $^{\mathrm{a}, \mathrm{b}}$, Artur Ferreira ${ }^{\mathrm{c}}$, Nereida Cordeiro ${ }^{\mathrm{a}, \mathrm{b}, *}$ \\ ${ }^{a}$ LB3, Faculty of Sciences and Engineering, University of Madeira, Campus Universitário da Penteada, 9020-105 Funchal, Portugal \\ ${ }^{\mathrm{b}}$ CIIMAR - Interdisciplinary Centre of Marine and Environmental Research, University of Porto, 4450-208 Matosinhos, Portugal \\ ${ }^{\mathrm{c}}$ CICECO - Aveiro Institute of Materials, Escola Superior de Tecnologia e Gestão de Águeda, University of Aveiro, 3810-193 Aveiro, Portugal
}

\section{A R T I C L E I N F O}

\section{Keywords:}

Nitrogen supplementation

Hemiselmis cf. andersenii

Chlorella stigmatophora

Lipidome analysis

Nutraceutical lipids

\begin{abstract}
A B S T R A C T
The current focus of algae biotechnology is the production of high-value lipids, and its improvement by employing abiotic perturbations such as nitrogen-induced changes. In the present study, the growth dynamics, nitrogen uptake, pigments, and lipid composition of Chlorella stigmatophora and Hemiselmis cf. andersenii were studied, in response to low (LN), medium (MN) and high (HN) nitrogen supplementations. Both microalgae responded to increased nitrogen levels by increasing their nitrogen uptake rate and pigment content. However, for lipid accumulation, C. stigmatophora presented a different pattern (LN: $16.56 \%>$ MN: 11.51\% > HN: 10.95\%) to that of $H$. cf. andersenii (MN: $15.37 \%>\mathrm{HN}: 13.06 \%>\mathrm{LN}$ : $6.71 \%$ ). Untargeted gas chromatography-mass spectrometry analysis allowed the visualization of the biochemical diversity of $C$. stigmatophora and $H$. cf. andersenii, as well as differences in lipid regulation upon nitrogen-induced changes among species. For instance, glycosyl sterols were only detected for $C$. stigmatophora samples grown under MN and HN conditions. Moreover, lipid analysis of $H$. cf. andersenii, before and after alkaline hydrolysis, suggests that wax esters play a key role in the response of this microalga to high nitrogen levels. The cultivation of $H$. cf. andersenii at MN and $\mathrm{HN}$ was shown to be ideal for providing a rich source of $\omega 3$ and polyunsaturated fatty acids for nutraceutical purposes. The hierarchical cluster analysis showed the differential intra- and interspecific effects of nitrogen on lipid composition. The diverse ways by which both microalgae responded to nitrogen-induced changes highlighted the influence of phylogeny on the carbon flux through metabolic networks, and accumulation.
\end{abstract}

\section{Introduction}

The active search by consumers for health-conscious foodstuffs has been a driving force for studying the chemical composition of microalgae. According to Bhattacharya and Goswami [1], worldwide small scale algal growth is estimated to generate US $\$ 6.5$ billion, of which US $\$ 2.5$ billion comes from the health food segment. However, one of the major limiting factors for the production of microalgae continues to be the low yield of biomass and extracted products [2]. To overcome this challenge, several strategies have been studied. For example, genetic engineering techniques, like introduction of new genes, elimination of non-essential assimilatory pathways, and biochemical engineering approaches, such as optimization of nutrient formulations, study of innovative cultivation techniques - utilization of plant growth regulators $[3,4]$.

Microalgal cells provide a biotechnological platform to modify, control and maximize the production of a targeted compound [5]. When considering algae as potential new food sources, one critical factor is their composition and nutritional content. Among lipids, the nutritional quality of microalgal species is positively associated with high levels of polyunsaturated fatty acids (PUFA), phytosterols and long-chain aliphatic alcohols (LCAA), which, in turn, can be transferred up the food-chain, adding commercial value to feeds and human dietary supplements [6-8]. Besides non-acylglycerol neutral lipids (hydrocarbons, free fatty acids, ketones), microalgae comprise polar (phospholipids and glycolipids) and acylglycerol lipids [9]. As with non-acylglycerol lipids, the quality of microalgae esterified lipid fraction is crucial for the selection of cultivation and processing strategies [10].

Microalgal lipid synthesis and accumulation can be enhanced through abiotic perturbations such as nitrogen-induced changes [11]. The main chemical forms by which photosynthetic organisms can acquire nitrogen include nitrate $\left(\mathrm{NO}_{3}^{-}\right)$, nitrite $\left(\mathrm{NO}_{2}^{-}\right)$, and ammonium

\footnotetext{
* Corresponding author at: LB3, Faculty of Sciences and Engineering, University of Madeira, Campus Universitário da Penteada, 9020-105 Funchal, Portugal.

E-mail address: ncordeiro@staff.uma.pt (N. Cordeiro).
} 
$\left(\mathrm{NH}_{4}^{+}\right)$[12]. Although the information on the regulation of nitrogen acquisition and assimilation is limited to few microalgal species, previous studies have shown that $\mathrm{NO}_{3}^{-}$is involved in the regulation of carbon-rich pools, such as carbohydrates and lipids [13]. In algae, $\mathrm{NO}_{3}^{-}$ acquisition and assimilation seem to be positively associated with its presence in the surrounding environment [13].

At the current stage of algal development, the production of biofuel from microalgal fatty acids is still a challenge due to high production costs. Therefore, the current focus of algae biotechnology is the production of high-value lipids [14]. Cryptophyte species have been shown to be rich sources of high-value products such as $\omega 3$-PUFA, carotenoids, phycobiliproteins, and sterols $[15,16]$. Belonging to the Cryptophyta division, Hemiselmis species lack heavy cell wall structures made of silica or cellulose, which, in turn, makes these microalgae easier to break down and process for commercial purposes $[16,17]$. In aquaculture industry, Hemiselmis is used as feed for fish hatcheries to improve growth and survival rates [18]. Although previous studies [17,19] have reported Cryptophyte Hemiselmis species as promising candidates for the sustainable and profitable production of health-promoting lipids, the modulation of Hemiselmis lipid quantity and composition is understudied. In this context, lipidomic studies are essential not only to reveal potential targets that may be of commercial interest, but also to understand lipid regulation in microalgae [20].

The Chlorophyta division contains the Chlorella genus, which is wellknown to generally possess rigid, recalcitrant cell walls [21]. Species from the Chlorella genus are known for their health benefits when consumed as a whole, and represent the first microalgal species to be produced on a large scale [22]. Thus, species from this genus have been extensively studied, comprising models when trying to understand the mechanisms that underlie desired product accumulation [22]. Although the divisions of $H$. cf. andersenii and $C$. stigmatophora are rather distinct, the potential of $H$. cf. andersenii for high-value compound exploitation was compared to $C$. stigmatophora as one of the few marine Chlorella studied for the commercial application of microalgae.

While many studies assessing the impact of nitrogen-limiting conditions have been performed, few information is known about the effect of excess nitrogen supplementation in microalgae [23]. Thereby, the aim of the present study was to determine how two diverse microalgal species remodeled their growth dynamics, nitrogen uptake, pigments, and especially lipid composition in response to three different nitrogen supplementations (low, medium, and high), using gas chromatography-mass spectrometry (GC-MS) untargeted analysis as a robust method for the identification of multiple metabolites.

\section{Materials and methods}

\subsection{Growth and culture conditions}

The Cryptophyta Hemiselmis cf. andersenii (BEA 0118B) was obtained from the Spanish Bank of Algae (BEA), and the seawater Chlorophyta Chlorella stigmatophora (RCC 661) was obtained from the Roscoff Culture Collection (RCC). The f/2-Si medium [24,25] $\left(8.82 \times 10^{-4} \mathrm{M} \mathrm{NaNO}_{3}\right.$, $3.62 \times 10^{-5} \mathrm{M} \mathrm{NaH}_{2} \mathrm{PO}_{4} \cdot \mathrm{H}_{2} \mathrm{O}, 1.06 \times 10^{-4} \mathrm{M} \mathrm{Na}_{2} \mathrm{SiO}_{3}, 1.17 \times 10^{-5} \mathrm{M}$ $\mathrm{FeCl}_{3} \cdot 6 \mathrm{H}_{2} \mathrm{O}, 1.17 \times 10^{-5} \mathrm{M} \mathrm{Na} \mathrm{Na}_{2}$ EDTA. $2 \mathrm{H}_{2} \mathrm{O}, 9.10 \times 10^{-7} \mathrm{M}$ $\mathrm{MnCl}_{2} \cdot 4 \mathrm{H}_{2} \mathrm{O}, 7.65 \times 10^{-8} \mathrm{M} \mathrm{ZnSO}_{4} \cdot 7 \mathrm{H}_{2} \mathrm{O}, 4.20 \times 10^{-8} \mathrm{M} \mathrm{CoCl}_{2} \cdot 6 \mathrm{H}_{2} \mathrm{O}$, $3.93 \times 10^{-8} \mathrm{M} \mathrm{CuSO}_{4} \cdot 5 \mathrm{H}_{2} \mathrm{O}, 2.60 \times 10^{-8} \mathrm{M} \mathrm{Na}_{2} \mathrm{MoO}_{4} \cdot 2 \mathrm{H}_{2} \mathrm{O}, 2.96 \times$ $10^{-7} \mathrm{M}$ Thiamine.HCl, $2.05 \times 10^{-9} \mathrm{M}$ Biotin, $3.69 \times 10^{-10}$ M Cyanocobalamin) was used as the basal formula for the nitrogen manipulations, with an initial $\mathrm{pH}$ of 7, measured with a HI $2209 \mathrm{pH}$ meter from Hannah instruments. The microalgae were grown under three different nutrient conditions by tailoring the nitrate concentrations: nitrogenlimited (low nitrogen - LN; $177 \pm 11 \mu \mathrm{M} \mathrm{NaNO}$ ), control (medium nitrogen $-\mathrm{MN} ; 989 \pm 13 \mu \mathrm{M} \mathrm{NaNO}_{3}$ ) and supplemented (high nitrogen $-\mathrm{HN} ; 1768 \pm 14 \mu \mathrm{M} \mathrm{NaNO} 3$ ). For the cultivation of the microalgae, $100 \mathrm{~mL}$ of exponentially growing microalgae was inoculated in $1 \mathrm{~L}$ flasks, giving the following initial cell concentrations: $4.95 \times 10^{5}$ cells
$\mathrm{mL}^{-1}$ for $H$. cf. andersenii, and $7.90 \times 10^{5}$ cells $\mathrm{mL}^{-1}$ for $C$. stigmatophora, and grown under $70 \mu \mathrm{mol} \mathrm{m}^{-2} \mathrm{~s}^{-1}$ light intensity, 16:8 h (light: dark cycles) at $25{ }^{\circ} \mathrm{C}$. In the early stationary phase, the medium was centrifuged for $7 \mathrm{~min}$ at $3720 \times \mathrm{g}$, the supernatant was discarded, and the pellets were washed twice with an $0.09 \mathrm{~g} \mathrm{~L}^{-1} \mathrm{NaCl}$ solution before being freeze-dried in a Labconco freeze dry system (Freezezone 4.5, Labconco) at $-50{ }^{\circ} \mathrm{C}$ for nearly 3 days and stored at $-20{ }^{\circ} \mathrm{C}$ until further analysis. According to Safafar et al. [26] storage of freeze-dried microalgae at low temperature is more effective for increasing storage stability of biomass than oxygen-reduced storage conditions (e.g. vacuum packaging). The number of microalgal cells was monitored daily by measuring the optical density of the microalgal culture at $550 \mathrm{~nm}\left(\mathrm{OD}_{550}\right)$ with an ultraviolet/visible spectrophotometer (UV-6300PC, VWR, China), $\mathrm{R}^{2}=$ 0.9929. The logistic model of Xin et al. [27] was used to describe the microalgal growth and fitted to the data with excel add-in solver.

\subsection{Nitrogen $\left(\mathrm{NO}_{3}^{-}-\mathrm{N}\right)$ determination}

Nitrogen (N) was determined as nitrate $\left(\mathrm{NO}_{3}^{-}\right)$by the ultraviolet spectrophotometric screening method previously reported by Wan et al. [28]. Briefly, a calibration curve $\left(\mathrm{R}^{2}=0.9999\right)$ was performed using $220 \mathrm{~nm}$ optical density $\left(\mathrm{OD}_{220}\right)$ against nitrogen concentrations (0-4.07 $\mathrm{mg} \mathrm{L}^{-1}$ ) from $\mathrm{NaNO}_{3}$ solutions. The rate of $\mathrm{N}$ uptake by microalgal cells (Eq. (1)) was calculated as follows:

Cell $\mathrm{N}$ uptake rate $\left(\mathrm{pg} \mathrm{N}\right.$ cell $\left.^{-1} \mathrm{~d}^{-1}\right)=\left(\frac{\mathrm{N}_{\mathrm{i}}-\mathrm{N}_{\mathrm{f}}}{\mathrm{X}_{\mathrm{t}}}\right) \times 100$

where $N_{i}$ is the initial nitrogen concentration ( $\mathrm{pg} \mathrm{L}^{-1}$ ), $\mathrm{N}_{\mathrm{f}}$ is the final nitrogen concentration (pg L ${ }^{-1}$ ) and $X_{t}$ is the cell concentration (cells $\mathrm{L}^{-1}$ ) at time $\mathrm{t}(\mathrm{d})$.

\subsection{Elemental analysis}

The elemental analysis of carbon (C), hydrogen $(H)$, nitrogen $(N)$, and sulfur (S) was performed on an elemental analyser Truspec 630-200200 , LECO, USA. For elemental analysis, up to $10 \mathrm{mg}$ of microalgal dried biomass were combusted in a furnace at $1075^{\circ} \mathrm{C}$. Then, the combustion gases were carried out using Helium, and further detected by infrared absorption (C, H, and S) and thermal conductivity (N).

\subsection{Chlorophylls and carotenoids determination}

Pigment extraction was performed from $10 \mathrm{mg}$ freeze-dried biomass with an $80 \%$ acetone solution. Samples were ultrasonicated for $90 \mathrm{~min}$, and centrifuged at $4430 \times g$ for $10 \mathrm{~min}$. The supernatant was removed, and the pellet was continuously washed until the supernatant became colorless. The supernatant was passed through a $0.45 \mu \mathrm{m}$ filter, and its absorbance was read in a spectrophotometer (UV-6300PC, VWR). The pigment content was calculated according to Chen and Vaidyanathan [29] by Eqs. (2)-(4), where Chl $a$ is the chlorophyll $a\left(\mu \mathrm{g} \mathrm{mL}{ }^{-1}\right), \mathrm{Chl} b$ is the chlorophyll $b\left(\mu \mathrm{g} \mathrm{mL}^{-1}\right)$, and $\mathrm{C}_{\mathrm{t}}$ is the carotenoids $\left(\mu \mathrm{g} \mathrm{mL}^{-1}\right)$ :

Chl $a=12.21 \mathrm{~A}_{663}-2.81 \mathrm{~A}_{646}$

Chl $b=20.13 \mathrm{~A}_{646}-5.03 \mathrm{~A}_{663}$

$\mathrm{C}_{\mathrm{t}}=\frac{1000 \mathrm{~A}_{470}-3.27 \mathrm{Chl} a-104 \mathrm{Chl} b}{198}$

Marine Chlorella stigmatophora belongs to the Chlorophyta division, which possesses chlorophylls $a$ and $b$, whereas Hemiselmis cf. andersenii is a marine microalga belonging to the Cryptophyta division, which only possesses chlorophylls $a$ and $c_{2}[15,30]$. Thus, for Cryptophyta $H$. cf. andersenii, chlorophyll $c_{2}$ determination was performed using the equation described by Jeffrey and Humphrey [30]. Thus, acetone from the supernatant was evaporated on a nitrogen stream and the remaining water was removed by freeze-drying samples. Afterwards, the samples 
were resuspended on $100 \%$ acetone. Chl $c_{2}$ is the chlorophyll $c_{2}$ ( $\mu \mathrm{g}$ $\mathrm{mL}^{-1}$ ), which was calculated by the following equation:

Chl $c_{2}=27.09 \mathrm{~A}_{630}-3.63 \mathrm{~A}_{663}$

\subsection{Lipid extraction}

Total lipids were estimated according to Bligh and Dyer [31], with some modifications as described by Fernandes et al. [32]. Briefly, $50-100 \mathrm{mg}$ of lyophilized microalgal biomass was used to estimate total lipids. Lipids were extracted with a methanol:chloroform mixture (2:1; $\mathrm{v}: \mathrm{v}$ ), followed by $400 \mu \mathrm{L}$ of a saturated solution of $\mathrm{KCl}$ and $2 \mathrm{~mL}$ of chloroform. After homogenization, $2 \mathrm{~mL}$ of distilled water was added. The organic phase was removed, and the remaining biomass was continuously washed until the organic phase became colorless. Then, the organic phase was transferred to pre-weighted tubes and dried under a nitrogen stream. The extracted lipids were left to stabilize in a desiccator prior to gravimetric quantification and stored at $-20{ }^{\circ} \mathrm{C}$ until further analysis.

\subsection{Alkaline hydrolysis}

Alkaline hydrolysis was performed to detect molecules in their esterified forms according to Santos et al. [33]. $0.5 \mathrm{M}$ of $\mathrm{NaOH}$ in aqueous methanol was added to two lipid aliquots, and the mixtures were heated at $100{ }^{\circ} \mathrm{C}$ for $1 \mathrm{~h}$ in a nitrogen atmosphere. Then, the samples were acidified to $\mathrm{pH} 2$ with $1 \mathrm{M} \mathrm{HCl}$.

\subsection{Gas chromatography-mass spectrometry (GC-MS) analysis}

Prior to GC-MS analysis, bis(trimethylsilyl)trifluoroacetamide (BSTFA) silylation of lipid extracts before and after alkaline hydrolysis was performed as described by Santos et al. [33]. Then, trimethylsilyl (TMS) derivatives were analyzed in a gas chromatographer $(6890 \mathrm{~N}$, Agilent Technologies, China) equipped with a mass selective detector (5973Network, Agilent Technologies, USA) and a ValcoBond capillary column from Vici Valco $(30 \mathrm{~m} \times 0.25 \mathrm{~mm}$ inner diameter, $0.25 \mu \mathrm{m}$ film thickness). The chromatographic conditions were those described in Fernandes et al. [19]. Briefly, the oven was set to $80{ }^{\circ} \mathrm{C}$ for $5 \mathrm{~min}$, increasing by $4{ }^{\circ} \mathrm{C} \mathrm{min}{ }^{-1}$ until $208{ }^{\circ} \mathrm{C}$, then by $2{ }^{\circ} \mathrm{C} \mathrm{min}{ }^{-1}$ until $260{ }^{\circ} \mathrm{C}$ and by $5{ }^{\circ} \mathrm{C} \min ^{-1}$ until the final temperature of $300{ }^{\circ} \mathrm{C}$, which was maintained for $4 \mathrm{~min}$. The injector temperature was $250^{\circ} \mathrm{C}$, the transfer line temperature was $290^{\circ} \mathrm{C}$, and the split ratio was 33:1. Helium was used as the carrier gas at a rate of $1.0 \mathrm{~mL} \mathrm{~min}^{-1}$. The identification of the extracted compounds as TMS derivatives was done by comparison of the mass spectra fragmentation with those from the Wiley-NIST library, literature [34-37], and when possible, by comparison with standards. For quantitative analysis, GC-MS was calibrated with pure reference compounds (mannose, trans-ferulic acid, nonadecan-1-ol, eicosan-1-ol, $5 \alpha$-chlolestane, cholesterol, stigmasterol, hexadecanoic, and nonadecanoic acids) relative to tetracosane (internal standard).

The hypocholesterolaemic/hypercholesterolaemic fatty acid ratio $(\mathrm{H} / \mathrm{H})$, as in Santos-Silva et al. [38], was calculated as follows (Eq. (6)):

$$
\begin{aligned}
\mathrm{H} / \mathrm{H} & =(\mathrm{C} 18: 1 \omega 9+\mathrm{C} 18: 2 \omega 6+\mathrm{C} 20: 4 \omega 6+\mathrm{C} 18: 3 \omega 3+\mathrm{C} 20: 5 \omega 3+\mathrm{C} 22 \\
& : 5 \omega 3+\mathrm{C} 22: 6 \omega 3) /(\mathrm{C} 14: 0+\mathrm{C} 16: 0)
\end{aligned}
$$

\subsection{Statistical analysis}

Statistical analysis of the data was carried out using the software IBM SPSS Statistics 24. Differences between treatments were assessed with one-way analysis of variance (ANOVA) followed by a Tukey post hoc analysis, with $p<0.05$ considered statistically significant. Metaboanalyst 3.0 was used to perform multivariate analysis and metabolitemetabolite correlation analysis [39]. Prior to the data analysis, variables were median normalized, $\log _{2}$ transformed and auto scaled. For hierarchical clustering heat maps, the Euclidean clustering distance and ward clustering method were used.

\section{Results and discussion}

\subsection{Culture growth and nitrogen removal assessment}

Chlorella stigmatophora and Hemiselmis cf. andersenii were grown under three different nitrogen conditions and sampled in the early stationary phase. The harvest days were determined as those on which the cell concentration was similar for 2 to 3 consecutive counting days; this was further corroborated by the non-significant differences found for the last cultivation days in both microalgae $(p>0.05)$. Fig. 1a shows the growth curves obtained for $C$. stigmatophora. Through this figure it is possible to see that the early stationary phase was reached at different days with respect to nitrogen supplementation: day 9 for LN conditions; and day 15 for MN and $\mathrm{HN}$ conditions. Meanwhile, in $\mathrm{H}$. cf. andersenii (Fig. 1b), strong effects on microalgal cell growth were also observed, with the early stationary phase being reached at day 6 for LN conditions and day 8 for both MN and HN conditions.

Changes in total nitrogen (Fig. 1c and d) in the growth medium showed that both microalgae grown in LN conditions internalized the available nitrogen by day 1 , confirming the initiation of nutrientdepleted conditions. In MN conditions, nitrogen was fully internalized by day 7 and day 6 for $C$. stigmatophora and $H$. cf. andersenii, respectively. These observations indicate that $C$. stigmatophora and $H$. cf. andersenii, under $\mathrm{LN}$ and MN cultivation conditions, continue to utilize the acquired nitrogen to support cell growth and division until they reach the early stationary phase. In both microalgae cultured under HN conditions, the nitrogen has not been fully consumed, which seemed to indicate that light-limitation occurred [40,41]. According to Lee et al. [41] cell concentration of a photosynthetic culture will continue to increase exponentially until all photosynthetically available photons are absorbed. Therefore, to verify if light-limitation did occur half the cells were returned to the conditioned media, and cell concentration was evaluated against time. For this assay, non-significant differences ( $p>$ 0.05 ) were found for cell concentration, and the highest variation rate observed for cell concentration was only $5 \%$, indicating that a return to exponential growth did not occurred, which, in turn, shows that the assumption of light-limitation was not accurate. Thus, with the increase in initial nitrogen concentrations, a stoichiometric imbalance between nitrogen and other nutrients in the culture medium was created, which may have caused the primary growth limiting nutrient to be a different nutrient (like phosphorus) than nitrogen.

Nitrogen supplementation triggered changes in the elemental stoichiometry of both microalgae (Table 1). An interesting observation is that despite $H$. cf. andersenii under LN conditions had presented the lowest nitrogen content, this microalga presented the lowest (3.00) carbon to nitrogen ratio $(\mathrm{C} / \mathrm{N})$. This observation, along with the carbon content, indicates that $\mathrm{LN}$ conditions lead to reduced carbon fixation. In C. stigmatophora, the $\mathrm{C} / \mathrm{N}$ ratio decreased by as much as $61 \%$ with nitrogen supplementation indicating that this microalga responded to higher nitrogen supplementation by allocating a larger proportion of carbon into nitrogen-rich pools like protein [32]. Changes in the elemental stoichiometry of microalgae in response to nutrient-induced have also been reported in other microalgae like Rhodomonas marina, Nannochloropsis gaditana, Isochrysis sp., and Chlorella vulgaris [32,42].

Under nitrogen-rich conditions, nitrogen is mainly integrated in the key structural components of microalgae, such as proteins and chlorophylls, needed to sustain cell growth [43]. In both microalgae under examination, chlorophylls and carotenoids displayed an increasing trend with nitrogen enrichment (Table 1). The observation that the lowest values were observed at $\mathrm{LN}$ conditions for both $C$. stigmatophora and $H$. cf. andersenii pigments seems to indicate that these microalgae respond to low nitrogen supplementations by triggering the degradation 
a)

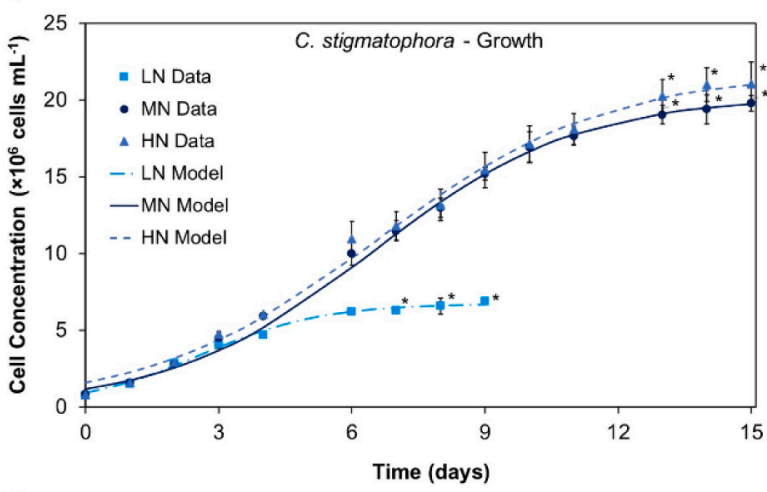

b)

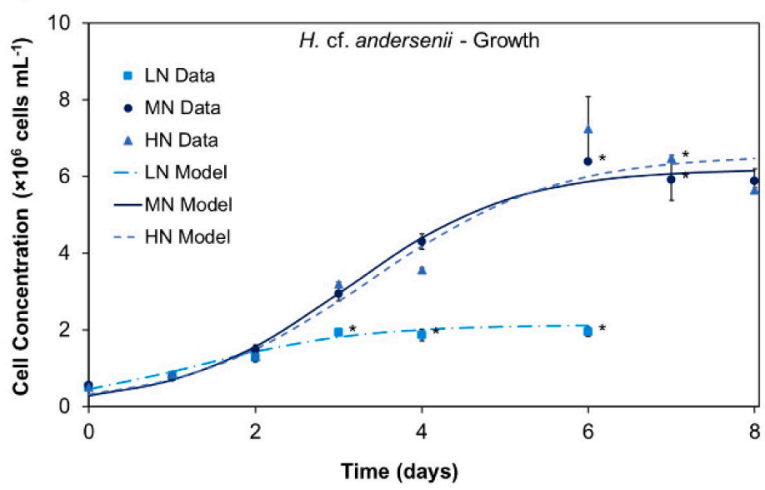

c)

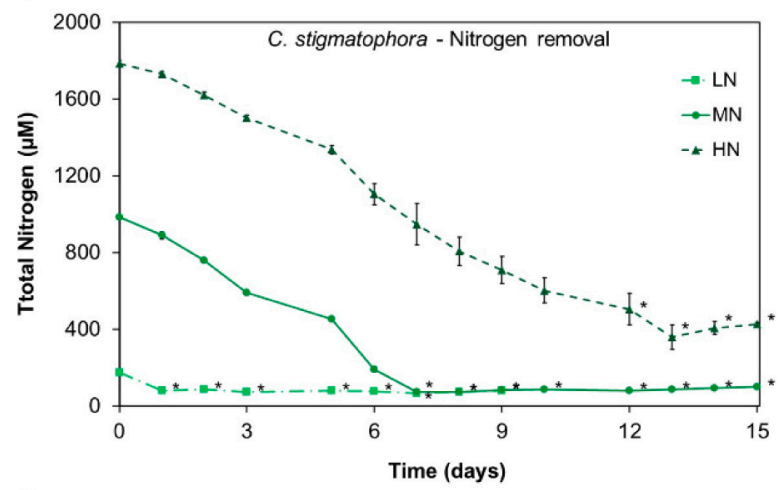

d)

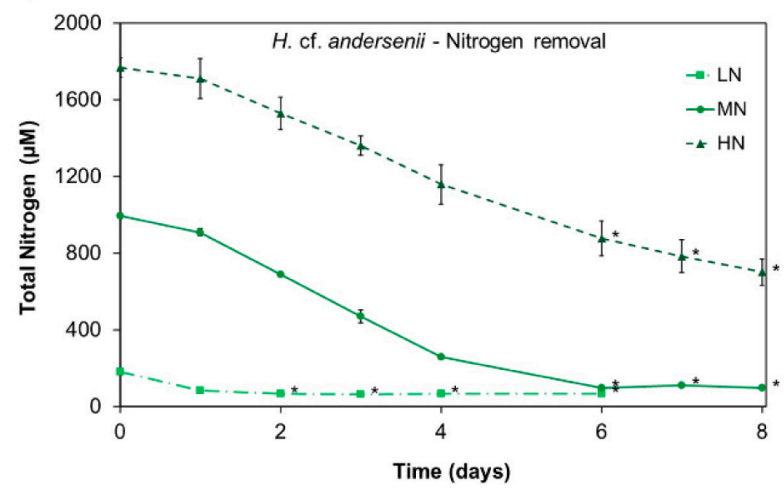

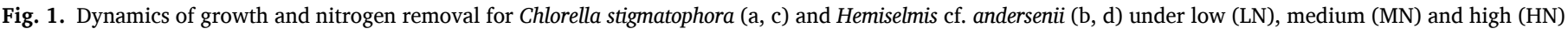

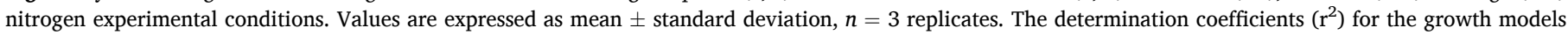
were higher than 0.90 . *Values are not significantly different $(p>0.05)$ among cultivation days, within each treatment.

of the photosynthetic machinery, in search of alternative nitrogen sources for protein synthesis to fulfil cell requirements [44].

The great biodiversity attributed to microalgae is reflected in the diverse ways by which core metabolic networks operate in microalgal species [45]. C. stigmatophora and $H$. cf. andersenii showed similar trends with respect to their cell uptake rate, which increased significantly ( $p<$ 0.05 ) with growth medium nitrogen concentrations (Table 1). For lipid accumulation, the trend displayed by both microalgae was different. For C. stigmatophora, the lipid content significantly $(p<0.05)$ decreased from $\mathrm{LN}(16.56 \% \mathrm{dw})$ to $\mathrm{MN}(11.51 \% \mathrm{dw})$ and $\mathrm{HN}(10.95 \% \mathrm{dw})$ treatments by as much as $34 \%$, whereas for $H$. cf. andersenii, the lipid content significantly $(p<0.05)$ increased up to 2.74 times with increasing nitrogen concentrations, from $\mathrm{LN}(6.49 \% \mathrm{dw})$ to $\mathrm{MN}(15.37 \% \mathrm{dw})$ and $\mathrm{HN}$ $(13.06 \% \mathrm{dw})$. Phylogeny determines to a large extent the efficiency of various steps involved in the desired product accumulation [45]. Moreover, intracellular organizational differences across evolutionarydistinct classes of microalgae may affect processes, such as photosynthesis, carbon flux through metabolic networks, and accumulation [45]. Thus, the highest $\mathrm{C} / \mathrm{N}$ ratio (32.61) and lipid content $(16.56 \% \mathrm{dw})$ observed at LN conditions suggests that $C$. stigmatophora responded to nitrogen-limiting conditions by increasing its intracellular composition in carbon rich pools like lipids. In contrast, $H$. cf. andersenii seemed to have displaced its efforts towards nitrogen storage, evidenced by the lowest $\mathrm{C} / \mathrm{N}$ ratio (3.00) and lipid content (6.49\%) obtained at $\mathrm{LN}$ conditions.

\subsection{Lipid variability in response to nitrogen supplementation}

Knowing that different lipid classes accumulate under specific growth stages, the early stationary phase was selected for the harvest and analysis of microalgal biomass, as it is often considered the best compromise for the simultaneous exploitation of PUFA and other high- value products, such as proteins and pigments [46]. Detailed lipidomic analysis (Fig. S1) revealed that $C$. stigmatophora and $H$. cf. andersenii exhibited different strategies of lipid metabolism in response to nitrogen supplementation. The lipid profiles of both microalgae revealed the presence of 66 metabolites, including fatty acids, aliphatic alcohols, sterols, monoglycerides, and other compounds (Tables 2 and 3). Significant differences $(p<0.05)$ were found for the metabolites analyzed across treatments. The analysis of $H$. cf. andersenii and $C$. stigmatophora samples before and after alkaline hydrolysis showed that $H$. cf. andersenii samples were more affected by alkaline hydrolysis than $C$. stigmatophora samples. Alkaline hydrolysis targets the ester bonds of lipids like acylglycerols, wax, and sterols esters [19]. Thus, the small changes verified for $C$. stigmatophora samples after alkaline hydrolysis might be justified by its lipid composition being richer in non-acyl lipids (like alkylglycerols) and lipid soluble compounds (such as carotenoids), which are stable to alkaline hydrolysis [19].

Through Fig. 2, it is possible to observe that the relative abundance of MUFA and PUFA significantly $(p<0.05)$ increased from LN to MN and HN treatments. This increase seems to have been achieved at the expense of SFA, which significantly $(p<0.05)$ decreased from LN to MN and HN treatments, in both microalgae. These results indicate that different nitrogen supplementations lead to membrane remodelling to respond to nitrogen-induced changes in both species studied. The degree of unsaturation of biological membranes affects their flexibility and functionality [47]. Moreover, it is known that membrane fluidity and permeability increase with the unsaturation degree of biological membranes [48]. Comparing these results with the nitrogen uptake, it is possible to observe that microalgal cell uptake in both species increased with the unsaturation degree of fatty acid, corroborating the previous assumption.

C. stigmatophora responded to increasing nitrogen supplementation by decreasing fatty acid levels (Tables 2 and 3), namely C16:0 and 
Table 1

Nutrient removal, cell uptake, cell uptake rate, biomass, cell dry weight, lipid content, protein content, and elemental analysis of Chlorella stigmatophora and Hemiselmis cf. andersenii under low, medium, and high nitrogen supplementation.

\begin{tabular}{|c|c|c|c|c|c|c|}
\hline & \multicolumn{3}{|c|}{ C. stigmatophora } & \multicolumn{3}{|c|}{ H. cf. andersenii } \\
\hline & Low & Medium & High & Low & Medium & High \\
\hline $\begin{array}{l}\text { Cell } \\
\qquad \begin{array}{l}\text { uptake } \\
\text { rate (pg } \\
\text { cell }^{-1} \\
\mathrm{~d}^{-1} \text { ) }\end{array}\end{array}$ & $\begin{array}{l}0.02 \pm \\
0.00^{\mathrm{a}}\end{array}$ & $\begin{array}{l}0.04 \pm \\
0.00^{\mathrm{b}}\end{array}$ & $\begin{array}{l}0.06 \pm \\
0.00^{\mathrm{c}}\end{array}$ & $\begin{array}{l}0.16 \pm \\
0.02^{\mathrm{A}}\end{array}$ & $\begin{array}{l}0.27 \pm \\
0.01^{\mathrm{B}}\end{array}$ & $\begin{array}{l}0.34 \pm \\
0.02^{\mathrm{C}}\end{array}$ \\
\hline $\begin{array}{c}\text { DCW (pg } \\
\text { cell }^{-1} \text { ) }\end{array}$ & $\begin{array}{l}26.32 \\
\pm 3.19^{\mathrm{a}}\end{array}$ & $\begin{array}{l}28.35 \pm \\
3.31^{\mathrm{a}}\end{array}$ & $\begin{array}{l}23.36 \\
\pm 1.52^{\mathrm{a}}\end{array}$ & $\begin{array}{l}105.54 \\
\pm 2.66^{\mathrm{A}}\end{array}$ & $\begin{array}{l}39.43 \pm \\
3.18^{\mathrm{B}}\end{array}$ & $\begin{array}{l}33.65 \\
\pm \\
3.04^{\mathrm{B}}\end{array}$ \\
\hline $\begin{array}{l}\text { Lipid (\% } \\
\text { dw) }\end{array}$ & $\begin{array}{l}16.56 \\
\pm 0.75^{\mathrm{a}}\end{array}$ & $\begin{array}{l}11.51 \pm \\
1.26^{\mathrm{b}}\end{array}$ & $\begin{array}{l}10.95 \\
\pm \\
0.52^{\mathrm{b}}\end{array}$ & $\begin{array}{l}6.49 \pm \\
1.22^{\mathrm{A}}\end{array}$ & $\begin{array}{l}15.37 \pm \\
1.38^{\mathrm{B}}\end{array}$ & $\begin{array}{l}13.06 \\
\pm \\
0.52^{C}\end{array}$ \\
\hline $\begin{array}{c}\text { Chl } a(\mathrm{mg} \\
\left.\mathrm{g}^{-1}\right)\end{array}$ & $\begin{array}{l}2.01 \pm \\
0.03^{\mathrm{a}}\end{array}$ & $\begin{array}{l}5.20 \pm \\
0.13^{\mathrm{b}}\end{array}$ & $\begin{array}{l}8.01 \pm \\
0.48^{c}\end{array}$ & $\begin{array}{l}0.34 \pm \\
0.01^{\mathrm{A}}\end{array}$ & $\begin{array}{l}3.31^{ \pm} \\
0.01^{\mathrm{B}}\end{array}$ & $\begin{array}{l}3.10 \pm \\
0.00^{\mathrm{C}}\end{array}$ \\
\hline $\begin{array}{c}\text { Chl } b \text { and } \\
\text { Chl } c_{2} \\
(\mathrm{mg} \\
\left.\mathrm{g}^{-1}\right)^{*}\end{array}$ & $\begin{array}{l}0.50 \pm \\
0.02^{\mathrm{a}}\end{array}$ & $\begin{array}{l}1.30 \pm \\
0.01^{\mathrm{b}}\end{array}$ & $\begin{array}{l}2.14 \pm \\
0.13^{c}\end{array}$ & $\begin{array}{l}0.28 \pm \\
0.00^{\mathrm{A}}\end{array}$ & $\begin{array}{l}0.74 \pm \\
0.10^{\mathrm{A}}\end{array}$ & $\begin{array}{l}0.65 \pm \\
0.07^{\mathrm{A}}\end{array}$ \\
\hline $\begin{array}{c}\mathrm{C}_{\mathrm{t}}(\mathrm{mg} \\
\left.\mathrm{g}^{-1}\right)\end{array}$ & $\begin{array}{l}0.89 \pm \\
0.02^{\mathrm{a}}\end{array}$ & $\begin{array}{l}2.31 \pm \\
0.05^{\mathrm{b}}\end{array}$ & $\begin{array}{l}3.10 \pm \\
0.22^{\mathrm{c}}\end{array}$ & $\begin{array}{l}0.12 \pm \\
0.00^{\mathrm{A}}\end{array}$ & $\begin{array}{l}1.94 \pm \\
0.01^{\mathrm{B}}\end{array}$ & $\begin{array}{l}0.64 \pm \\
0.00^{\mathrm{C}}\end{array}$ \\
\hline$C(\% d w)$ & $\begin{array}{l}29.70 \\
\pm 1.41^{\mathrm{a}}\end{array}$ & $\begin{array}{l}30.11 \pm \\
1.91^{\mathrm{a}}\end{array}$ & $\begin{array}{l}35.98 \\
\pm \\
1.35^{\mathrm{b}}\end{array}$ & $\begin{array}{l}4.18 \pm \\
0.04^{\mathrm{A}}\end{array}$ & $\begin{array}{l}27.29 \pm \\
0.37^{\mathrm{B}}\end{array}$ & $\begin{array}{l}24.24 \\
\pm \\
0.00^{\mathrm{C}}\end{array}$ \\
\hline N (\% dw) & $\begin{array}{l}1.06 \pm \\
0.02^{\mathrm{a}}\end{array}$ & $\begin{array}{l}1.75 \pm \\
0.03^{\mathrm{b}}\end{array}$ & $\begin{array}{l}3.27 \pm \\
0.06^{\mathrm{c}}\end{array}$ & $\begin{array}{l}1.63 \pm \\
0.10^{\mathrm{A}}\end{array}$ & $\begin{array}{l}3.27 \pm \\
0.00^{\mathrm{B}}\end{array}$ & $\begin{array}{l}4.68 \pm \\
0.02^{C}\end{array}$ \\
\hline $\mathrm{H}(\% \mathrm{dw})$ & $\begin{array}{l}4.59 \pm \\
0.21^{\mathrm{a}}\end{array}$ & $\begin{array}{l}4.48 \pm \\
0.21^{\mathrm{a}}\end{array}$ & $\begin{array}{l}4.97 \pm \\
0.23^{\mathrm{a}}\end{array}$ & $\begin{array}{l}2.12 \pm \\
0.13^{\mathrm{A}}\end{array}$ & $\begin{array}{l}4.30 \pm \\
0.11^{\mathrm{B}}\end{array}$ & $\begin{array}{l}3.81 \pm \\
0.06^{\mathrm{C}}\end{array}$ \\
\hline $\begin{array}{c}\mathrm{C} / \mathrm{N}(\mathrm{mol} / \\
\mathrm{mol})\end{array}$ & $\begin{array}{l}32.61 \\
\pm 1.57^{\mathrm{a}}\end{array}$ & $\begin{array}{l}20.06 \pm \\
0.96^{\mathrm{b}}\end{array}$ & $\begin{array}{l}12.82 \\
\pm 0.24^{\mathrm{c}}\end{array}$ & $\begin{array}{l}3.00 \pm \\
0.20^{\mathrm{A}}\end{array}$ & $\begin{array}{l}9.72 \pm \\
0.19^{\mathrm{B}}\end{array}$ & $\begin{array}{l}6.04 \pm \\
0.03^{\mathrm{C}}\end{array}$ \\
\hline
\end{tabular}

Values (means \pm SD of at least two replicates) in the same row, not sharing a common superscript are significantly different $(p<0.05)$. Differences among treatments assessed by one-way ANOVA followed by Tukey post-hoc analysis are represented by superscript lowercase letters for $C$. stigmatophora, and by superscript uppercase letters for $H$. cf. andersenii. DCW: dry cell weight; Chl $a$ : chlorophyll $a$; Chl $b$ : C hlorophyll $b$; Chl $c_{2}$ : Chlorophyll $c_{2} ; \mathrm{C}_{\mathrm{t}}$ : total carotenoids. Sulfur was not detected for $C$. stigmatophora and $H$. cf. andersenii samples regardless treatments applied.

* Chlorophyll $b$ was estimated for C. stigmatophora, and chlorophyll $c_{2}$ was estimated for $H$. cf. andersenii.

octadecanoic (C18:0) acids, which are products of de novo fatty acid synthesis in the chloroplast and comprise the substrates needed for MUFA, and PUFA biosynthesis [48]. Meanwhile, in H. cf. andersenii, significant shifts in fatty acid composition caused by increased nitrogen enrichment became visible in higher amounts of hexadecanoic (C16:0), 9-hexadecenoic (C16:1 $\omega 7)$, 9,12,15-octadecatrienoic acid (C18:3 $\omega 3$; ALA), 5,8,11,14,17-eicosapentaenoic acid (C20:5 $\omega 3$; EPA), and 4,7,10,13,16,19-docosahexaenoic acid (C22:6ஸ3; DHA).

Fatty acids were the most affected by alkaline hydrolysis, increasing up to 31 and $71 \%$ in C. stigmatophora and $H$. cf. andersenii, respectively. In $C$. stigmatophora the most affected individual fatty acids by hydrolysis

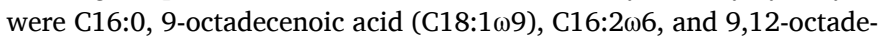
cadienoic (LA; C18:206) acids, with the biggest increase being verified for C18:1 $\omega 9$, representing a fourfold increase with alkaline hydrolysis. C16:0 and C18:2 fatty acids have been reported in literature as abundant molecular species on the glycolipid's composition of Chlorella sp. [49]. Moreover, for other microalgae belonging to Chlorophyta division, like Chlamydomonas reinhardtii and Chlamydomonas nivalis, C18:1 fatty acids were reported to be major components of glycolipids [49]. Thus, the increase in the mentioned fatty acids after alkaline hydrolysis for C. stigmatophora may be because they are associated with glycolipids.

As with $C$. stigmatophora, $H$. cf. andersenii presented noticeable changes in fatty acid levels after hydrolysis, namely a great increase in tetradecanoic (C14:0), C16:0, ALA, and EPA contents. These variations were more pronounced with nitrogen enrichment, with C14:0 fatty acid presenting a threefold increase. According to Guschina and Harwood [50], the plastidial glycosylglycerolipids of marine algae may contain very-long chain PUFA like EPA, in addition to ALA and C16:0. As main components of photosynthetic membranes, microalgae naturally possess high amounts of glycolipids when grown in nutrient-repleted conditions [32]. Thus, in both microalgae, the similar behavior of chlorophylls, along with the mentioned fatty acids increase after alkaline hydrolysis with nitrogen enrichment, suggests that these might be structural components of glycolipids.

A higher relative abundance of aliphatic alcohols was found for $H$. cf. andersenii cultured under LN conditions (up to $41 \%$ of total identified compounds). Most aliphatic alcohols occur in marine organisms as wax esters, which serve several purposes in organisms, such as energy storage and buoyancy generation [51]. Moreover, these compounds have been reported to exist in cryptophytes, namely in Chroomonas salina [52]. In $H$. cf. andersenii at MN and HN conditions, alcohols increased by as much as $39 \%$, along with total fatty acids. These results indicate that, towards HN conditions, alcohols are mainly esterified with fatty acids (wax esters). In C. stigmatophora aliphatic alcohols presented a similar trend to lipids and fatty acids in response to nitrogen influence. However, after alkaline hydrolysis, a significant increase in total alcohols was not observed, indicating that these compounds are not in wax esters forms, in contrast to $H$. cf. andersenii.

3,7,11,15-Tetramethyl-2-hexadecen-1-ol (phytol) was found in its lowest amount in $H$. cf. andersenii under $\mathrm{LN}$ conditions $\left(0.98 \mathrm{mg} \mathrm{g}^{-1}\right.$ $\mathrm{dw}$ ). When comparing samples before and after alkaline hydrolysis, this compound was the most affected by alkaline hydrolysis, increasing up to $145 \%$. According to Yao et al. [53], this aliphatic alcohol can be used as an indicator of chlorophylls, enabling inspection of the algal cell response when exposed to low nitrogen supplementation [44]. However, in C. stigmatophora, the phytol content before and after alkaline hydrolysis did not present the same behavior as chlorophylls. In addition to chlorophylls, phytol is a component of other biological molecules, namely vitamin K, vitamin E, and other tocopherols [54]. As $\alpha$-tocopherol was detected in C. stigmatophora (Tables 2 and 3), this could be a reasonable explanation for the different behavior shown by C. stigmatophora. Therefore, these results indicate that phytol is a good indicator of chlorophyll content for $H$. cf. andersenii but not for C. stigmatophora.

Monoglyceride content displayed a similar trend to lipid content with nitrogen supplementation, showing, once more, that both microalgae differently modified their lipid quantity and quality in response to nitrogen. That is, $H$. cf. andersenii monoglyceride content displayed a positive trend with nitrogen supplementation, in contrast to C. stigmatophora, which responded to increasing nitrogen supplementation by decreasing monoglyceride levels. According to Zienkiewicz et al. [55], two major pathways of triacylglycerol synthesis have been proposed to function in microalgae: $i$ ) Kennedy or glycerol phosphate pathway, and ii) monoacylglycerol pathway. The observed similar trend of lipids with monoacylglycerides upon treatments suggests that these molecules are important intermediates in anabolic fatty acid ester pathways in the microalgae studied. Thus, at LN conditions C. stigmatophora seemed to store carbon as triacylglycerols, in opposition to $H$. cf. andersenii.

Glycosyl sterols were only found for C. stigmatophora before hydrolysis under MN and HN conditions. These biomolecules have unique amphiphilic properties that make them suitable to be applied in food and pharmaceutical fields [34,56]. Moreover, glycosyl sterols have been reported to exist for other microalgae species belonging to Chlorophyta division, namely Tetraselmis chui, Scenedesmus coastatum, and Platymonas helgolandica $[56,57]$. Thus, the presence of glycosyl sterols under MN and $\mathrm{HN}$ conditions revealed the potential of these conditions for food and pharmaceutical applications.

In $H$. cf. andersenii, the increases in $24 \alpha$-methylcholest-5-en-3 $\beta$-ol and $24 \alpha$-ethylcholest-5-en- $3 \beta$-ol sterols by 30 and $45 \%$, respectively, 
Table 2

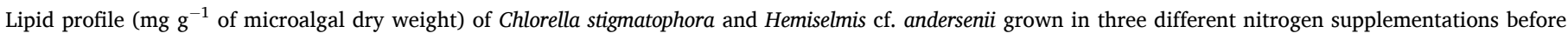
alkaline hydrolysis.

\begin{tabular}{|c|c|c|c|c|c|c|c|}
\hline \multirow[t]{2}{*}{ No. } & \multirow[t]{2}{*}{ Identified Compounds } & \multicolumn{3}{|c|}{ Chlorella stigmatophora } & \multicolumn{3}{|c|}{ Hemiselmis cf. andersenii } \\
\hline & & Low & Medium & High & Low & Medium & High \\
\hline & Fatty acids & $42.97 \pm 1.00^{a}$ & $32.38 \pm 1.27^{b}$ & $31.33 \pm 0.96^{b}$ & $26.64 \pm 0.26^{A}$ & $53.92 \pm 0.37^{B}$ & $40.09 \pm 1.15^{C}$ \\
\hline & Saturated & $26.03 \pm 0.23 a$ & $17.75 \pm 0.73^{b}$ & $17.19 \pm 0.43^{b}$ & $17.49 \pm 0.12^{A}$ & $27.68 \pm 0.43^{B}$ & $20.43 \pm 0.64^{C}$ \\
\hline 1 & Nonanoic acid & $1.53 \pm 0.01^{\mathrm{a}}$ & $1.03 \pm 0.01^{\mathrm{b}}$ & $1.02 \pm 0.01^{\mathrm{b}}$ & $1.04 \pm 0.00^{\mathrm{A}}$ & $1.55 \pm 0.00^{\mathrm{B}}$ & $1.03 \pm 0.01^{\mathrm{C}}$ \\
\hline 3 & Decanoic acid & $1.53 \pm 0.01^{\mathrm{a}}$ & $1.03 \pm 0.01^{\mathrm{b}}$ & $1.01 \pm 0.00^{c}$ & $1.04 \pm 0.00^{\mathrm{A}}$ & $1.55 \pm 0.02^{\mathrm{B}}$ & $1.02 \pm 0.01^{\mathrm{A}}$ \\
\hline 6 & Undecanoic acid & $1.52 \pm 0.01^{\mathrm{a}}$ & $1.03 \pm 0.02^{\mathrm{b}}$ & $1.00 \pm 0.00^{\mathrm{c}}$ & n.d. & n.d. & n.d. \\
\hline 8 & Dodecanoic acid & $1.53 \pm 0.01^{\mathrm{a}}$ & $1.03 \pm 0.01^{\mathrm{b}}$ & $1.01 \pm 0.00^{\mathrm{c}}$ & $1.03 \pm 0.00^{\mathrm{A}}$ & $1.54 \pm 0.01^{\mathrm{B}}$ & $1.02 \pm 0.01^{\mathrm{A}}$ \\
\hline 11 & Tetradecanoic acid & $1.55 \pm 0.01^{\mathrm{a}}$ & $1.08 \pm 0.01^{\mathrm{b}}$ & $1.05 \pm 0.01^{\mathrm{c}}$ & $1.10 \pm 0.00^{\mathrm{A}}$ & $1.97 \pm 0.17^{\mathrm{B}}$ & $1.22 \pm 0.01^{\mathrm{A}}$ \\
\hline 12 & Pentadecanoic acid & $1.54 \pm 0.01^{\mathrm{a}}$ & $1.05 \pm 0.01^{\mathrm{b}}$ & $1.02 \pm 0.01^{\mathrm{c}}$ & $1.06 \pm 0.01^{\mathrm{A}}$ & $1.59 \pm 0.01^{\mathrm{B}}$ & $1.06 \pm 0.02^{\mathrm{A}}$ \\
\hline 20 & Hexadecanoic acid & $3.34 \pm 0.17^{\mathrm{a}}$ & $2.43 \pm 0.47^{\mathrm{b}}$ & $2.31 \pm 0.25^{\mathrm{b}}$ & $2.69 \pm 0.07^{\mathrm{A}}$ & $5.67 \pm 0.19^{\mathrm{B}}$ & $5.44 \pm 0.34^{\mathrm{B}}$ \\
\hline 22 & Heptadecanoic acid & $1.71 \pm 0.04^{\mathrm{a}}$ & $1.18 \pm 0.05^{\mathrm{b}}$ & $1.16 \pm 0.00^{\mathrm{b}}$ & $1.28 \pm 0.01^{\mathrm{A}}$ & $1.80 \pm 0.09^{\mathrm{B}}$ & $1.23 \pm 0.05^{\mathrm{A}}$ \\
\hline 29 & Octadecanoic acid & $2.36 \pm 0.12^{\mathrm{a}}$ & $1.51 \pm 0.21^{\mathrm{b}}$ & $1.44 \pm 0.10^{\mathrm{b}}$ & $1.82 \pm 0.02^{\mathrm{A}}$ & $2.45 \pm 0.01^{\mathrm{B}}$ & $2.02 \pm 0.09^{C}$ \\
\hline 36 & Eicosanoic acid & $1.64 \pm 0.07^{\mathrm{a}}$ & $1.11 \pm 0.06^{\mathrm{b}}$ & $1.04 \pm 0.03^{\mathrm{b}}$ & $1.06 \pm 0.00^{\mathrm{A}}$ & $1.57 \pm 0.01^{\mathrm{B}}$ & $1.05 \pm 0.01^{\mathrm{A}}$ \\
\hline 43 & Docosanoic acid & $1.59 \pm 0.01^{\mathrm{a}}$ & $1.08 \pm 0.01^{\mathrm{b}}$ & $1.06 \pm 0.01^{\mathrm{c}}$ & $1.12 \pm 0.01^{\mathrm{A}}$ & $1.64 \pm 0.04^{\mathrm{B}}$ & $1.10 \pm 0.03^{\mathrm{A}}$ \\
\hline 45 & Tricosanoic acid & $1.54 \pm 0.00^{\mathrm{a}}$ & $1.04 \pm 0.00^{\mathrm{b}}$ & $1.02 \pm 0.01^{\mathrm{c}}$ & $1.05 \pm 0.01^{\mathrm{A}}$ & $1.58 \pm 0.02^{\mathrm{B}}$ & $1.04 \pm 0.01^{\mathrm{A}}$ \\
\hline 49 & Tetracosanoic acid & $1.54 \pm 0.00^{\mathrm{a}}$ & $1.05 \pm 0.00^{\mathrm{b}}$ & $1.02 \pm 0.01^{\mathrm{c}}$ & $1.05 \pm 0.00^{\mathrm{A}}$ & $1.57 \pm 0.00^{\mathrm{B}}$ & $1.05 \pm 0.02^{\mathrm{A}}$ \\
\hline 56 & Octacosanoic acid & $1.54 \pm 0.01^{\mathrm{a}}$ & $1.04 \pm 0.00^{\mathrm{b}}$ & $1.01 \pm 0.01^{\mathrm{c}}$ & $1.07 \pm 0.01^{\mathrm{A}}$ & $1.59 \pm 0.01^{\mathrm{B}}$ & $1.07 \pm 0.01^{\mathrm{A}}$ \\
\hline \multirow{2}{*}{60} & Triacontanoic acid & $1.55 \pm 0.01^{\mathrm{a}}$ & $1.04 \pm 0.01^{\mathrm{b}}$ & $1.02 \pm 0.01^{\mathrm{b}}$ & $1.07 \pm 0.01^{\mathrm{A}}$ & $1.61 \pm 0.02^{\mathrm{B}}$ & $1.08 \pm 0.01^{\mathrm{A}}$ \\
\hline & Monounsaturated & $8.33 \pm 0.63^{a}$ & $7.52 \pm 0.49^{a b}$ & $7.20 \pm 0.37^{b}$ & $4.37 \pm 0.03^{A}$ & $11.40 \pm 0.03^{B}$ & $8.06 \pm 0.13^{C}$ \\
\hline 17 & 7-Hexadecenoic acid & $1.63 \pm 0.02^{\mathrm{a}}$ & $1.21 \pm 0.02^{\mathrm{b}}$ & $1.11 \pm 0.02^{\mathrm{c}}$ & $1.05 \pm 0.00^{\mathrm{A}}$ & $3.17 \pm 0.03^{\mathrm{B}}$ & $2.11 \pm 0.02^{\mathrm{C}}$ \\
\hline 18 & 9-Hexadecenoic acid ${ }^{1}$ & n.d. & $1.03 \pm 0.01^{\mathrm{a}}$ & $1.01 \pm 0.01^{\mathrm{b}}$ & $1.03 \pm 0.00^{\mathrm{A}}$ & $1.58 \pm 0.01^{\mathrm{B}}$ & $1.12 \pm 0.02^{\mathrm{C}}$ \\
\hline 27 & 9-Octadecenoic acid & $3.40 \pm 0.54^{\mathrm{a}}$ & $3.04 \pm 0.46^{\mathrm{a}}$ & $2.89 \pm 0.28^{\mathrm{a}}$ & $1.20 \pm 0.01^{\mathrm{A}}$ & $1.77 \pm 0.04^{\mathrm{B}}$ & $1.21 \pm 0.03^{\mathrm{A}}$ \\
\hline 28 & 11-Octadecenoic acid & $1.75 \pm 0.10^{\mathrm{a}}$ & $1.19 \pm 0.05^{\mathrm{b}}$ & $1.18 \pm 0.05^{\mathrm{b}}$ & $1.09 \pm 0.02^{\mathrm{A}}$ & $1.78 \pm 0.02^{\mathrm{B}}$ & $1.50 \pm 0.04^{C}$ \\
\hline 30 & 10-Nonadecenoic acid & n.d. & n.d. & n.d. & n.d. & $1.56 \pm 0.01^{\mathrm{A}}$ & $1.07 \pm 0.02^{\mathrm{B}}$ \\
\hline 32 & 12-Nonadecenoic acid & n.d. & n.d. & n.d. & n.d. & $1.56 \pm 0.01^{\mathrm{A}}$ & $1.05 \pm 0.01^{\mathrm{B}}$ \\
\hline \multirow[t]{2}{*}{35} & 11-Eicosenoic acid & $1.55 \pm 0.01^{\mathrm{a}}$ & $1.04 \pm 0.01^{\mathrm{b}}$ & $1.01 \pm 0.01^{\mathrm{c}}$ & n.d. & n.d. & n.d. \\
\hline & Polyunsaturated & $8.61 \pm 0.24^{a}$ & $7.12 \pm 0.20^{b}$ & $6.94 \pm 0.17^{b}$ & $4.78 \pm 0.16^{A}$ & $14.84 \pm 0.11^{B}$ & $11.59 \pm 0.39^{C}$ \\
\hline 14 & $\mathrm{C} 16: 2 \omega 6$ & $1.64 \pm 0.02^{\mathrm{a}}$ & $1.35 \pm 0.03^{b}$ & $1.26 \pm 0.02^{\mathrm{c}}$ & n.d. & n.d. & n.d. \\
\hline 15 & $\mathrm{C} 16: 3 \omega 3$ & $1.62 \pm 0.01^{\mathrm{a}}$ & $1.29 \pm 0.01^{\mathrm{b}}$ & $1.20 \pm 0.02^{\mathrm{c}}$ & n.d. & n.d. & n.d. \\
\hline 16 & 7,12-Hexadienoic acid & n.d. & n.d. & n.d. & n.d. & $1.60 \pm 0.02^{\mathrm{A}}$ & $1.17 \pm 0.02^{\mathrm{B}}$ \\
\hline 19 & Methyl-4,7,10,13-hexadecatetraenoate & n.d. & n.d. & n.d. & $1.04 \pm 0.01^{\mathrm{A}}$ & $1.59 \pm 0.01^{\mathrm{B}}$ & $1.09 \pm 0.01^{\mathrm{C}}$ \\
\hline 25 & 9,12-Octadecadienoic acid & $1.95 \pm 0.10^{\mathrm{a}}$ & $1.82 \pm 0.12^{\mathrm{a}}$ & $1.86 \pm 0.08^{\mathrm{a}}$ & $1.14 \pm 0.09^{\mathrm{A}}$ & $1.89 \pm 0.05^{\mathrm{B}}$ & $1.28 \pm 0.03^{\mathrm{C}}$ \\
\hline 26 & $9,12,15$-Octadecatrienoic acid & $1.85 \pm 0.14^{\mathrm{a}}$ & $1.60 \pm 0.06^{\mathrm{b}}$ & $1.59 \pm 0.03^{b}$ & $1.45 \pm 0.08^{\mathrm{A}}$ & $3.83 \pm 0.05^{\mathrm{B}}$ & $3.16 \pm 0.16^{\mathrm{C}}$ \\
\hline 33 & 5,8,11,14,17-Eicosapentaenoic acid & $1.55 \pm 0.01^{\mathrm{a}}$ & $1.06 \pm 0.00^{\mathrm{b}}$ & $1.03 \pm 0.01^{\mathrm{c}}$ & $1.14 \pm 0.00^{\mathrm{A}}$ & $2.65 \pm 0.02^{\mathrm{B}}$ & $2.51 \pm 0.13^{\mathrm{B}}$ \\
\hline 38 & $4,7,10,13,16,19-$ Docosahexaenoic acid & n.d. & n.d. & n.d. & n.d. & $1.62 \pm 0.01^{\mathrm{A}}$ & $1.16 \pm 0.02^{\mathrm{B}}$ \\
\hline \multirow[t]{2}{*}{39} & 7,10,13,16,19-Docosapentaenoic acid & n.d. & n.d. & n.d. & n.d. & $1.64 \pm 0.01^{\mathrm{A}}$ & $1.24 \pm 0.03^{\mathrm{B}}$ \\
\hline & Alcohols & $23.84 \pm 1.00^{a}$ & $17.79 \pm 1.21^{b}$ & $17.59 \pm 0.30^{b}$ & $19.91 \pm 0.20^{A}$ & $27.07 \pm 2.53^{B}$ & $19.74 \pm 1.21^{A}$ \\
\hline 2 & Decanol & $1.24 \pm 0.01^{\mathrm{a}}$ & $0.85 \pm 0.02^{\mathrm{b}}$ & $0.82 \pm 0.01^{\mathrm{b}}$ & $0.95 \pm 0.01^{\mathrm{A}}$ & $1.34 \pm 0.02^{\mathrm{B}}$ & $0.96 \pm 0.04^{\mathrm{A}}$ \\
\hline 4 & Undecanol & $1.27 \pm 0.01^{\mathrm{a}}$ & $0.88 \pm 0.04^{b}$ & $0.86 \pm 0.02^{\mathrm{b}}$ & $1.04 \pm 0.02^{\mathrm{A}}$ & $1.36 \pm 0.02^{\mathrm{B}}$ & $0.99 \pm 0.03^{\mathrm{C}}$ \\
\hline 7 & Dodecanol & $1.26 \pm 0.01^{\mathrm{a}}$ & $0.88 \pm 0.04^{\mathrm{b}}$ & $0.86 \pm 0.04^{b}$ & $0.95 \pm 0.02^{\mathrm{A}}$ & $1.32 \pm 0.02^{\mathrm{B}}$ & $0.92 \pm 0.02^{\mathrm{A}}$ \\
\hline 9 & Tridecanol & $1.31 \pm 0.01^{\mathrm{a}}$ & $0.95 \pm 0.04^{\mathrm{b}}$ & $0.95 \pm 0.06^{\mathrm{b}}$ & $1.07 \pm 0.06^{\mathrm{A}}$ & $1.34 \pm 0.05^{\mathrm{B}}$ & $0.94 \pm 0.02^{\mathrm{C}}$ \\
\hline 10 & Tetradecanol & $1.35 \pm 0.02^{\mathrm{a}}$ & $0.92 \pm 0.02^{\mathrm{b}}$ & $0.92 \pm 0.00^{\mathrm{b}}$ & $0.99 \pm 0.02^{\mathrm{A}}$ & $1.46 \pm 0.05^{\mathrm{B}}$ & $0.98 \pm 0.04^{\mathrm{A}}$ \\
\hline 13 & Hexadecanol & $2.55 \pm 0.28^{\mathrm{a}}$ & $1.94 \pm 0.39^{b}$ & $1.98 \pm 0.08^{b}$ & $2.68 \pm 0.12^{\mathrm{AB}}$ & $3.10 \pm 0.66^{\mathrm{A}}$ & $2.21 \pm 0.25^{\mathrm{B}}$ \\
\hline 21 & Octadece-9-nol & $3.51 \pm 0.47^{\mathrm{a}}$ & $2.64 \pm 0.65 a$ & $2.68 \pm 0.09^{\mathrm{a}}$ & $3.70 \pm 0.09^{\mathrm{A}}$ & $4.22 \pm 1.09^{\mathrm{A}}$ & $3.06 \pm 0.40^{\mathrm{A}}$ \\
\hline 23 & Octadecanol & $2.12 \pm 0.18^{\mathrm{a}}$ & $1.51 \pm 0.23^{\mathrm{b}}$ & $1.51 \pm 0.04^{\mathrm{b}}$ & $1.88 \pm 0.05^{\mathrm{AB}}$ & $2.33 \pm 0.37^{\mathrm{A}}$ & $1.67 \pm 0.18^{\mathrm{B}}$ \\
\hline 34 & Eicosanol & $1.29 \pm 0.01^{\mathrm{a}}$ & $0.87 \pm 0.01^{\mathrm{b}}$ & $0.86 \pm 0.00^{\mathrm{b}}$ & $0.90 \pm 0.01^{\mathrm{A}}$ & $1.32 \pm 0.02^{\mathrm{B}}$ & $0.88 \pm 0.01^{\mathrm{A}}$ \\
\hline 40 & Docosanol & $1.25 \pm 0.00^{\mathrm{a}}$ & $0.84 \pm 0.00^{\mathrm{b}}$ & $0.82 \pm 0.01^{\mathrm{c}}$ & $0.85 \pm 0.00^{\mathrm{A}}$ & $1.28 \pm 0.01^{\mathrm{B}}$ & $0.86 \pm 0.01^{\mathrm{A}}$ \\
\hline 50 & Hexacosanol & n.d. & $0.84 \pm 0.00^{\mathrm{a}}$ & $0.82 \pm 0.00^{\mathrm{b}}$ & n.d. & n.d. & n.d. \\
\hline 52 & Octacosanol & $1.49 \pm 0.05^{\mathrm{a}}$ & $1.04 \pm 0.06^{\mathrm{b}}$ & $1.03 \pm 0.01^{\mathrm{b}}$ & $1.08 \pm 0.02^{\mathrm{A}}$ & $1.53 \pm 0.12^{\mathrm{B}}$ & $1.04 \pm 0.03^{\mathrm{A}}$ \\
\hline 58 & Octacosane-1,3-diol & $1.31 \pm 0.01^{\mathrm{a}}$ & $0.89 \pm 0.01 b$ & $0.87 \pm 0.00^{\mathrm{b}}$ & $0.94 \pm 0.01^{\mathrm{A}}$ & $1.37 \pm 0.06^{\mathrm{B}}$ & $0.92 \pm 0.01^{\mathrm{A}}$ \\
\hline 59 & Triacontanol & $1.38 \pm 0.03^{\mathrm{a}}$ & $0.93 \pm 0.02^{\mathrm{b}}$ & $0.92 \pm 0.00^{\mathrm{b}}$ & $1.00 \pm 0.02^{\mathrm{A}}$ & $1.43 \pm 0.08^{\mathrm{B}}$ & $0.97 \pm 0.03^{\mathrm{A}}$ \\
\hline 61 & Dotriacontanol & $1.27 \pm 0.01^{\mathrm{a}}$ & $0.85 \pm 0.00^{\mathrm{b}}$ & $0.83 \pm 0.01^{\mathrm{c}}$ & $0.88 \pm 0.01^{\mathrm{A}}$ & $1.29 \pm 0.01^{\mathrm{B}}$ & $0.86 \pm 0.02^{\mathrm{A}}$ \\
\hline \multirow[t]{2}{*}{24} & $3,7,11,15$-Tetramethyl-2-hexadecen-1-ol & $1.26 \pm 0.01^{\mathrm{a}}$ & $0.96 \pm 0.12^{\mathrm{b}}$ & $0.86 \pm 0.01^{b}$ & $0.98 \pm 0.01^{\mathrm{A}}$ & $2.39 \pm 0.03^{\mathrm{B}}$ & $2.49 \pm 0.18^{\mathrm{A}}$ \\
\hline & Sterols & $2.15 \pm 0.20^{a}$ & $1.69 \pm 0.28^{b}$ & $1.56 \pm 0.04^{b}$ & $1.40 \pm 0.09^{A}$ & $2.95 \pm 0.39^{B}$ & $2.65 \pm 0.15$ \\
\hline 53 & $24 \beta$-Methylcholesta-5,22E-dien-3 $\beta$-ol & n.d. & n.d. & n.d. & $0.33 \pm 0.02^{\mathrm{A}}$ & $1.60 \pm 0.08^{\mathrm{B}}$ & $1.67 \pm 0.09^{\mathrm{B}}$ \\
\hline 54 & 24-Methylcholesta-5,24(28)-dien-3 $\beta$-ol & $0.27 \pm 0.01^{\mathrm{a}}$ & $0.21 \pm 0.01^{b}$ & $0.20 \pm 0.00^{\mathrm{b}}$ & n.d. & n.d. & n.d. \\
\hline 55 & $24 \alpha$-Methylcholest-5-en-3 $\beta$-ol & $0.31 \pm 0.02^{\mathrm{a}}$ & $0.26 \pm 0.03^{\mathrm{b}}$ & $0.25 \pm 0.01^{b}$ & $0.20 \pm 0.01^{\mathrm{A}}$ & $0.28 \pm 0.03^{\mathrm{B}}$ & $0.20 \pm 0.01^{\mathrm{A}}$ \\
\hline 57 & $24 \alpha$-Ethylcholest-5-en- $3 \beta$-ol & $1.27 \pm 0.16^{\mathrm{a}}$ & $1.02 \pm 0.22^{\mathrm{ab}}$ & $0.89 \pm 0.03^{b}$ & $0.62 \pm 0.06^{\mathrm{A}}$ & $0.73 \pm 0.25^{\mathrm{A}}$ & $0.53 \pm 0.05^{\mathrm{A}}$ \\
\hline 64 & Unidentified Sterol & $0.28 \pm 0.03^{\mathrm{a}}$ & $0.20 \pm 0.02^{\mathrm{b}}$ & $0.21 \pm 0.01^{\mathrm{b}}$ & $0.25 \pm 0.01^{\mathrm{A}}$ & $0.34 \pm 0.04^{\mathrm{B}}$ & $0.26 \pm 0.02^{\mathrm{A}}$ \\
\hline & Monoglycerides & $0.79 \pm 0.08^{a}$ & $0.68 \pm 0.07^{b}$ & $0.32 \pm 0.01^{b}$ & $0.14 \pm 0.04^{A}$ & $0.66 \pm 0.04^{B}$ & $1.58 \pm 0.26^{C}$ \\
\hline 31 & 2,3-Dihydroxypropyl dodecanoate & $0.06 \pm 0.01^{\mathrm{a}}$ & $0.06 \pm 0.01^{\mathrm{a}}$ & $0.05 \pm 0.00^{\mathrm{b}}$ & $0.06 \pm 0.02^{\mathrm{A}}$ & $0.07 \pm 0.03^{\mathrm{A}}$ & $0.09 \pm 0.06^{\mathrm{A}}$ \\
\hline 41 & 1,3-Dihydroxy-2-propanyl palmitate & $0.02 \pm 0.01^{\mathrm{a}}$ & $0.03 \pm 0.00^{\mathrm{b}}$ & n.d. & n.d. & $0.05 \pm 0.00^{\mathrm{A}}$ & $0.10 \pm 0.02^{\mathrm{B}}$ \\
\hline 42 & 2,3-Dihydroxypropyl palmitate & $0.35 \pm 0.04^{\mathrm{a}}$ & $0.28 \pm 0.03^{b}$ & $0.11 \pm 0.01^{\mathrm{c}}$ & $0.05 \pm 0.02^{\mathrm{A}}$ & $0.26 \pm 0.01^{\mathrm{B}}$ & $0.67 \pm 0.09^{C}$ \\
\hline 44 & 3-Octadecoxypropane-1,2-diol & $0.04 \pm 0.01^{\mathrm{a}}$ & $0.02 \pm 0.00^{\mathrm{b}}$ & $0.02 \pm 0.00^{\mathrm{b}}$ & $0.03 \pm 0.01^{\mathrm{A}}$ & $0.07 \pm 0.02^{\mathrm{B}}$ & $0.08 \pm 0.01^{\mathrm{B}}$ \\
\hline 46 & 1,3-Dihydroxy-2-propanyl stearate & n.d. & $0.02 \pm 0.00^{\mathrm{a}}$ & $0.01 \pm 0.00^{\mathrm{b}}$ & n.d. & $0.07 \pm 0.01^{\mathrm{A}}$ & $0.09 \pm 0.02^{\mathrm{B}}$ \\
\hline 47 & 2,3-Dihydroxypropyl 9-octadecenoate & n.d. & $0.02 \pm 0.00^{\mathrm{a}}$ & $0.03 \pm 0.00^{\mathrm{b}}$ & n.d. & n.d. & n.d. \\
\hline 48 & 2,3-Dihydroxypropyl stearate & $0.32 \pm 0.03^{\mathrm{a}}$ & $0.24 \pm 0.04^{\mathrm{b}}$ & $0.10 \pm 0.01^{\mathrm{c}}$ & n.d. & $0.15 \pm 0.01^{\mathrm{A}}$ & $0.55 \pm 0.08^{\mathrm{B}}$ \\
\hline & Others & $0.37 \pm 0.04^{a}$ & $0.57 \pm 0.09^{b}$ & $1.51 \pm 0.09^{c}$ & $0.08 \pm 0.05^{A}$ & $0.27 \pm 0.01^{B}$ & $0.18 \pm 0.06^{B}$ \\
\hline 5 & 2,6-bis(1,1-Dimethylethyl)phenol & $0.34 \pm 0.04^{\mathrm{a}}$ & $0.19 \pm 0.05^{\mathrm{b}}$ & $0.17 \pm 0.04^{\mathrm{b}}$ & $0.08 \pm 0.05^{\mathrm{A}}$ & $0.27 \pm 0.01^{\mathrm{B}}$ & $0.18 \pm 0.06^{\mathrm{B}}$ \\
\hline 51 & $\alpha$-Tocopherol & $0.03 \pm 0.01^{\mathrm{a}}$ & $0.08 \pm 0.02^{\mathrm{b}}$ & $0.06 \pm 0.01^{\mathrm{b}}$ & n.d. & n.d. & n.d. \\
\hline 62 & C28:2 Steryl glycoside & n.d. & $0.10 \pm 0.01^{\mathrm{a}}$ & $0.55 \pm 0.01^{b}$ & n.d. & n.d. & n.d. \\
\hline 63 & C28:3 Steryl glycoside & n.d. & $0.11 \pm 0.01^{\mathrm{a}}$ & $0.43 \pm 0.04^{b}$ & n.d. & n.d. & n.d. \\
\hline 65 & C28:2 Steryl glycoside & n.d. & $0.08 \pm 0.02^{\mathrm{a}}$ & $0.17 \pm 0.01^{\mathrm{b}}$ & n.d. & n.d. & n.d. \\
\hline
\end{tabular}


Table 2 (continued)

\begin{tabular}{|c|c|c|c|c|c|c|c|}
\hline \multirow[t]{2}{*}{ No. } & \multirow[t]{2}{*}{ Identified Compounds } & \multicolumn{3}{|c|}{ Chlorella stigmatophora } & \multicolumn{3}{|c|}{ Hemiselmis cf. andersenii } \\
\hline & & Low & Medium & High & Low & Medium & High \\
\hline 66 & $\begin{array}{l}\text { C28:3 Steryl glycoside } \\
\text { Total }\end{array}$ & $\begin{array}{l}\text { n.d. } \\
70.12 \pm 1.78^{a}\end{array}$ & $\begin{array}{l}\text { n.d. } \\
53.11 \pm 2.86^{b}\end{array}$ & $\begin{array}{l}0.13 \pm 0.02 \\
52.31 \pm 0.76^{b}\end{array}$ & $\begin{array}{l}\text { n.d. } \\
48.17 \pm 0.42^{A}\end{array}$ & $\begin{array}{l}\text { n.d. } \\
84.87 \pm 3.25^{B}\end{array}$ & $\begin{array}{l}\text { n.d. } \\
64.24 \pm 2.67^{C}\end{array}$ \\
\hline
\end{tabular}

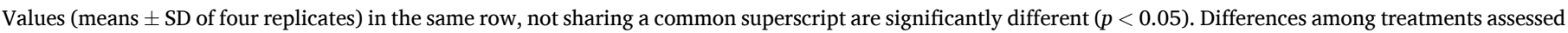

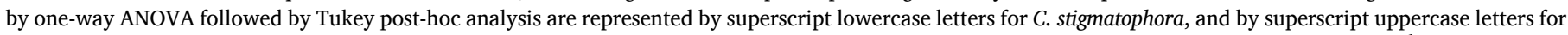

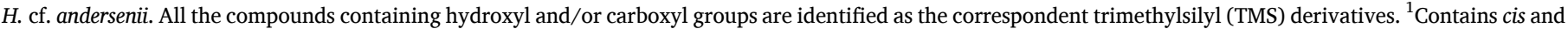
trans isomers. n.d. - non detected.

with alkaline hydrolysis at HN conditions, seem to indicate the presence of sterol esters in its lipid composition. Sterol esters have been reported to occur in other microalgae which, like $H$. cf. andersenii, belong to the kingdom Chromista, namely Isochrysis aff. galbana and Nannochloropsis salina $[57,58]$. Several assumptions have been made with respect to the physiological role of sterol conjugates, like: $i$ ) sterol conjugates are sterol storage pools which can be depleted when de novo synthesis of sterols is not sufficient, or to maintain the organization and fluidity of membranes; $i$ i) the esterification of sterols and fatty acids is essential to avoid membrane perturbations from elevated sterols or free fatty acid levels resulting in a critical homeostatic response [57]. Considering this, the possibility of the production of sterol esters by $H$. cf. andersenii, at HN conditions, seems to be related with the first assumption, since the highest fatty acid and sterol contents before hydrolysis were found in MN conditions instead of in HN conditions.

\subsection{Variations in microalgal nutritional value related to nitrogen supplementation}

Fig. 3 displays the changes in the fatty acid nutritional indexes in free and hydrolysable lipid fractions of the $C$. stigmatophora and $H$. cf. andersenii cultured in different nitrogen supplementations. Fatty acid ratios were calculated considering their functional effects. PUFA are one of the key functional ingredients synthesized by microalgae [47]. These essential nutrients play key roles as structural components of cell membranes and cytokine precursors [47,59]. Although these fatty acids have crucial roles in animals' growth and development, PUFA precursors (LA and ALA) can only be obtained through dietary intake, and further elongation and desaturation is not enzymatically efficient [59]. Moreover, as SFA are synthesized by animals, a high PUFA intake is recommended for the diet [47].

When analysing the polyunsaturated to saturated fatty acid ratio (PUFA/SFA) against the different nitrogen supplementations (Fig. 3), it was possible to observe that both microalgae responded to increasing nitrogen levels by increasing their PUFA/SFA ratios by around double after hydrolysis. A PUFA/SFA ratio above 0.45 is recommended to induce a decrease in blood cholesterol level [38]. In C. stigmatophora, PUFA/SFA ratios over 0.45 were only achieved in samples cultured in $\mathrm{MN}$ and $\mathrm{HN}$ conditions after cleavage of fatty acids ester bonds. Knowing that the bioavailability of fatty acids is important for its absorption by animals, and that fatty acids in its free form have increased absorption by humans [60], these results suggest that for the application of C. stigmatophora as a source of a healthy PUFA/SFA ratio, a pretreatment (e.g. chemical or enzymatic hydrolysis) of Chlorella lipids has to be performed. In $H$. cf. andersenii cultured at MN and HN conditions, PUFA/SFA ratios were higher than 0.45 , indicating that this microalgal strain is suitable for nutraceutical purposes, in contrast to $H$. cf. andersenii cultured in LN conditions.

Although for $C$. stigmatophora the $\omega 3$ to $\omega 6$ PUFA ratio $(\Sigma \omega 3 / \Sigma \omega 6)$ remained rather stable before and after alkaline hydrolysis, in $H$. cf. andersenii a positive trend between the $\Sigma \omega 3 / \Sigma \omega 6$ ratio and nitrogen supplementation was observed. In this microalgal species, the $\Sigma \omega 3 / \Sigma \omega 6$ ratio registered more than a twofold increase in response to increased nitrogen levels, suggesting that nitrogen supplementation affected the biosynthesis of PUFA by shifting enzyme specificity towards $\omega 3$ fatty acids synthesis instead of $\omega 6$ fatty acids [48]. The same trend was displayed for another Cryptophyta (Rhodomonas marina) in nutrient replete conditions [48]. The high values observed for $\omega 3$ fatty acids make $H$. cf. andersenii at high nitrogen supplementation a suitable microalgal strain for $\omega 3$ fatty acid supplementation. $\omega 6$ predominantly dominates Western diets, with its consumption being 20 times higher than that of $\omega 3$ fatty acids [19]. However, as main precursors of pro- and anti- inflammatory molecules (e.g. prostaglandins, and leukotrienes), a balanced $\Sigma \omega 3 / \Sigma \omega 6$ ratio close to $1: 1$ is recommended for the mitigation of inflammatory and chronic diseases [19]. Thus, the cultivation of $H$. cf. andersenii at MN and $\mathrm{HN}$ conditions is ideal to provide a rich source of $\omega 3$ fatty acids for nutraceutical purposes.

When stating that a product is a source of $\omega 3$ PUFA, one of the following requirements must be fulfilled: $i$ ) the product should have 0.3 $\mathrm{g}$ of $\mathrm{C} 18: 3 \omega 3$ per $100 \mathrm{~g}$ of product; or ii) EPA + DHA must be equal to or higher than $40 \mathrm{mg}$ per $100 \mathrm{~g}$ of product [19]. Without hydrolysis (Table 2), $H$. cf. andersenii samples under MN and HN conditions presented 383 and $316 \mathrm{mg}$ of $\mathrm{C} 18: 3 \omega 3$ per $100 \mathrm{~g}$ of dried algal biomass; and 427 and $367 \mathrm{mg}$ of EPA + DHA per $100 \mathrm{~g}$ of dried algal biomass, respectively. After alkaline hydrolysis processing (Table 3 ), $H$. cf. andersenii presented 994 and $616 \mathrm{mg}$ of C18:3 03 per $100 \mathrm{~g}$ of dried algal biomass; and 849 and $673 \mathrm{mg}$ of EPA + DHA per $100 \mathrm{~g}$ of dried algal biomass, at $\mathrm{MN}$ and $\mathrm{HN}$ conditions, respectively. These observations reinforce the previous assumption that $H$. cf. andersenii cultured at MN and $\mathrm{HN}$ condition is suitable for nutraceutical purposes. C. stigmatophora samples across treatments did not meet the above-mentioned criteria for C18:3 03 or for EPA + DHA.

Another indicator of the nutritional quality of lipids in food is the hypocholesterolaemic/hypercholesterolaemic fatty acids ratio $(\mathrm{H} / \mathrm{H})$. This nutritional index is calculated based on the knowledge of functional effects of individual fatty acids in the cholesterol metabolism, and higher values are considered to be beneficial for human health [38]. H/ $\mathrm{H}$ values observed for $C$. stigmatophora ranged from 1.79 to 2.73 , with the main contributors go the higher $\mathrm{H} / \mathrm{H}$ values being the high amounts of C18:1 $\omega 9$, in combination with low levels of C16:0. The major change in $\mathrm{H} / \mathrm{H}$ index found in $C$. stigmatophora was a significant $(p<0.05)$ increase (41\%) observed among LN and MN conditions after hydrolysis. In the $H$. cf. andersenii samples, the $\mathrm{H} / \mathrm{H}$ ratio varied between 1.00 and 1.76; in this microalgal species, the factor that contributed the most to the highest $\mathrm{H} / \mathrm{H}$ index was the increase in unsaturated fatty acid content, namely $\mathrm{C} 18: 3 \omega 3$ and $\mathrm{C} 20: 5 \omega 3$. Moreover, the greatest increase of $\mathrm{H} / \mathrm{H}$ value for $H$. cf. andersenii was between $\mathrm{LN}$ and MN conditions after hydrolysis (37\%). Since the hypocholesterolemic fatty acids reduce the low-density lipoproteins (bad cholesterol) [61], samples with the highest $\mathrm{H} / \mathrm{H}$ values $(>1)$ may be important as cholesterol-lowering agents. Moreover, the ability to improve this ratio by changing initial nitrogen concentrations comprises an advantage for the biotechnological exploitation of these microalgae.

Through the above-mentioned observations, it was possible to visualize that the way in which $C$. stigmatophora and $H$. cf. andersenii respond to nitrogen-induced changes was species-specific and affected their nutritional value. Moreover, the analysis after and before hydrolysis proved to be crucial, since it is a rapid and high throughput methodology that provides information about the desired product bioavailability (non-esterified or esterified), which influences not only the selection of 
Table 3

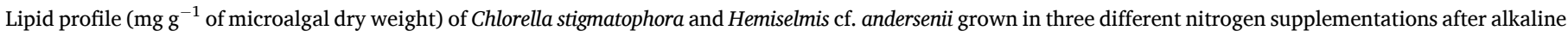
hydrolysis.

\begin{tabular}{|c|c|c|c|c|c|c|c|}
\hline \multirow[t]{2}{*}{ No. } & \multirow[t]{2}{*}{ Identified compounds } & \multicolumn{3}{|c|}{ Chlorella stigmatophora } & \multicolumn{3}{|c|}{ Hemiselmis cf. andersenii } \\
\hline & & Low & Medium & High & Low & Medium & High \\
\hline & Fatty acids & $48.01 \pm 2.09^{a}$ & $42.40 \pm 3.61^{b}$ & $40.05 \pm 1.23^{b}$ & $25.87 \pm 2.20^{A}$ & $85.84 \pm 4.40^{B}$ & $68.66 \pm 4.67^{C}$ \\
\hline & Saturated & $22.31 \pm 0.54^{a}$ & $14.59 \pm 0.82^{b}$ & $13.95 \pm 0.54^{b}$ & $15.35 \pm 1.22^{A}$ & $41.19 \pm 3.27^{B}$ & $32.66 \pm 1.75^{C}$ \\
\hline 1 & Nonanoic acid & $2.01 \pm 0.03^{\mathrm{a}}$ & $1.26 \pm 0.02^{\mathrm{b}}$ & $1.19 \pm 0.07^{\mathrm{b}}$ & $1.03 \pm 0.00^{\mathrm{A}}$ & $2.02 \pm 0.04^{\mathrm{B}}$ & $1.53 \pm 0.02^{\mathrm{C}}$ \\
\hline 3 & Decanoic acid & $2.01 \pm 0.03^{\mathrm{a}}$ & n.d. & $1.19 \pm 0.08^{b}$ & $1.01 \pm 0.00^{\mathrm{A}}$ & $2.02 \pm 0.04^{\mathrm{B}}$ & $1.52 \pm 0.00^{\mathrm{C}}$ \\
\hline 6 & Undecanoic acid & $2.02 \pm 0.02$ & n.d. & n.d. & n.d. & n.d. & n.d. \\
\hline 8 & Dodecanoic acid & $2.04 \pm 0.01^{\mathrm{a}}$ & $1.27 \pm 0.03^{\mathrm{b}}$ & $1.21 \pm 0.07^{\mathrm{b}}$ & $1.01 \pm 0.00^{\mathrm{A}}$ & $2.06 \pm 0.04^{\mathrm{B}}$ & $1.54 \pm 0.01^{\mathrm{C}}$ \\
\hline 11 & Tetradecanoic acid & $2.08 \pm 0.05^{\mathrm{a}}$ & $1.33 \pm 0.04^{\mathrm{b}}$ & $1.29 \pm 0.05^{\mathrm{b}}$ & $1.33 \pm 0.01^{\mathrm{A}}$ & $5.25 \pm 0.12^{\mathrm{B}}$ & $2.89 \pm 0.39^{\mathrm{C}}$ \\
\hline 12 & Pentadecanoic acid & $2.02 \pm 0.03^{\mathrm{a}}$ & $1.28 \pm 0.03^{\mathrm{b}}$ & $1.22 \pm 0.08^{\mathrm{b}}$ & $1.05 \pm 0.01^{\mathrm{A}}$ & $2.21 \pm 0.05^{\mathrm{B}}$ & $1.63 \pm 0.03^{C}$ \\
\hline 20 & Hexadecanoic acid & $5.37 \pm 0.27^{\mathrm{a}}$ & $4.95 \pm 0.55 a$ & $4.82 \pm 0.10^{\mathrm{a}}$ & $5.16 \pm 0.08^{\mathrm{A}}$ & $14.41 \pm 0.90^{\mathrm{B}}$ & $14.05 \pm 2.80^{\mathrm{B}}$ \\
\hline 22 & Heptadecanoic acid & $2.12 \pm 0.05^{\mathrm{a}}$ & $1.30 \pm 0.02^{\mathrm{b}}$ & $1.26 \pm 0.06^{\mathrm{b}}$ & $1.15 \pm 0.02^{\mathrm{A}}$ & $2.27 \pm 0.07^{\mathrm{B}}$ & $1.81 \pm 0.10^{\mathrm{C}}$ \\
\hline 29 & Octadecanoic acid & $2.64 \pm 0.08^{\mathrm{a}}$ & $1.93 \pm 0.11^{\mathrm{b}}$ & $1.76 \pm 0.04^{c}$ & $2.06 \pm 0.11^{\mathrm{A}}$ & $3.75 \pm 0.30^{\mathrm{AB}}$ & $3.76 \pm 0.01^{\mathrm{B}}$ \\
\hline 36 & Eicosanoic acid & n.d. & n.d. & n.d. & $1.02 \pm 0.01^{\mathrm{A}}$ & $2.04 \pm 0.04^{\mathrm{B}}$ & $1.58 \pm 0.04^{\mathrm{B}}$ \\
\hline 43 & Docosanoic acid & n.d. & $1.25 \pm 0.02$ & n.d. & $1.05 \pm 0.01^{\mathrm{A}}$ & $2.08 \pm 0.06^{\mathrm{B}}$ & $1.58 \pm 0.02^{\mathrm{B}}$ \\
\hline 45 & Tricosanoic acid & n.d. & n.d. & n.d. & n.d. & n.d. & $1.51 \pm 0.01$ \\
\hline 49 & Tetracosanoic acid & n.d. & n.d. & n.d. & n.d. & $2.04 \pm 0.05^{\mathrm{A}}$ & $1.52 \pm 0.01^{\mathrm{A}}$ \\
\hline \multirow[t]{2}{*}{60} & Triacontanoic acid & n.d. & n.d. & n.d. & n.d. & $2.05 \pm 0.03$ & n.d. \\
\hline & Monounsaturated & $15.65 \pm 1.12^{a b}$ & $15.93 \pm 1.87^{a}$ & $13.38 \pm 0.49^{b}$ & $5.34 \pm 0.59^{A}$ & $16.10 \pm 0.34^{B}$ & $14.93 \pm 2.02^{B}$ \\
\hline 17 & 7-Hexadecenoic acid & $2.39 \pm 0.07^{\mathrm{a}}$ & $2.06 \pm 0.10^{\mathrm{b}}$ & $2.06 \pm 0.11^{\mathrm{b}}$ & $1.06 \pm 0.02^{\mathrm{A}}$ & $4.28 \pm 0.09^{\mathrm{B}}$ & $3.25 \pm 0.02^{\mathrm{C}}$ \\
\hline 18 & 9-Hexadecenoic acid ${ }^{1}$ & $2.02 \pm 0.04^{\mathrm{a}}$ & $1.31 \pm 0.03^{\mathrm{b}}$ & $1.26 \pm 0.08^{\mathrm{b}}$ & $1.04 \pm 0.00^{\mathrm{A}}$ & $2.22 \pm 0.04^{\mathrm{B}}$ & $1.77 \pm 0.01^{\mathrm{C}}$ \\
\hline 27 & 9-Octadecenoic acid & $9.09 \pm 0.99^{\mathrm{a}}$ & $9.82 \pm 1.68^{\mathrm{a}}$ & $8.60 \pm 0.25^{\mathrm{a}}$ & $1.29 \pm 0.04^{\mathrm{A}}$ & $2.62 \pm 0.07^{\mathrm{B}}$ & $2.82 \pm 0.96^{\mathrm{B}}$ \\
\hline 28 & 11-Octadecenoic acid & $2.16 \pm 0.04^{\mathrm{a}}$ & $1.48 \pm 0.04^{\mathrm{b}}$ & $1.46 \pm 0.06^{\mathrm{b}}$ & $1.19 \pm 0.03^{\mathrm{A}}$ & $2.88 \pm 0.08^{\mathrm{B}}$ & $3.91 \pm 1.05^{\mathrm{B}}$ \\
\hline 30 & 10-Nonadecenoic acid & n.d. & n.d. & n.d. & n.d. & $2.06 \pm 0.03^{\mathrm{A}}$ & $1.61 \pm 0.01^{\mathrm{B}}$ \\
\hline 32 & 12-Nonadecenoic acid & n.d. & n.d. & n.d. & $1.01 \pm 0.00^{\mathrm{A}}$ & $2.04 \pm 0.03^{\mathrm{B}}$ & $1.57 \pm 0.01^{\mathrm{B}}$ \\
\hline \multirow[t]{2}{*}{35} & 11-Eicosenoic acid & n.d. & $1.26 \pm 0.02$ & n.d. & n.d. & n.d. & n.d. \\
\hline & Polyunsaturated & $10.04 \pm 0.43^{a}$ & $11.89 \pm 0.94^{b}$ & $12.72 \pm 0.21 b$ & $5.18 \pm 0.39^{A}$ & $28.54 \pm 0.88^{B}$ & $21.07 \pm 0.95^{C}$ \\
\hline 14 & $\mathrm{C} 16: 2 \omega 6$ & $2.34 \pm 0.09^{\mathrm{a}}$ & $2.35 \pm 0.15^{\mathrm{b}}$ & $2.75 \pm 0.11^{\mathrm{b}}$ & n.d. & n.d. & n.d. \\
\hline 15 & $\mathrm{C} 16: 3 \omega 3$ & $2.38 \pm 0.07^{\mathrm{a}}$ & $2.15 \pm 0.10^{\mathrm{b}}$ & $2.28 \pm 0.09^{\mathrm{ab}}$ & n.d. & n.d. & n.d. \\
\hline 16 & 7,12-Hexadienoic acid & n.d. & n.d. & n.d. & n.d. & $2.26 \pm 0.05^{\mathrm{A}}$ & $1.82 \pm 0.04^{\mathrm{B}}$ \\
\hline 19 & Methyl-4,7,10,13-hexadecatetraenoate & n.d. & n.d. & n.d. & n.d. & $2.03 \pm 0.04^{\mathrm{A}}$ & $1.52 \pm 0.01^{\mathrm{B}}$ \\
\hline 25 & 9,12-Octadecadienoic acid & $2.82 \pm 0.17^{\mathrm{a}}$ & $3.53 \pm 0.43^{\mathrm{b}}$ & $3.97 \pm 0.11^{\mathrm{b}}$ & $1.28 \pm 0.02^{\mathrm{A}}$ & $3.26 \pm 0.03^{\mathrm{B}}$ & $2.74 \pm 0.61^{B}$ \\
\hline 26 & $9,12,15$-Octadecatrienoic acid & $2.50 \pm 0.11^{\mathrm{a}}$ & $2.56 \pm 0.23 a$ & $2.53 \pm 0.04^{\mathrm{a}}$ & $2.58 \pm 0.23^{\mathrm{A}}$ & $9.94 \pm 0.46^{\mathrm{B}}$ & $6.16 \pm 0.13^{\mathrm{C}}$ \\
\hline 33 & 5,8,11,14,17-Eicosapentaenoic acid & n.d. & $1.29 \pm 0.04^{\mathrm{a}}$ & $1.20 \pm 0.08^{\mathrm{a}}$ & $1.31 \pm 0.14^{\mathrm{A}}$ & $6.05 \pm 0.21^{B}$ & $4.80 \pm 0.14^{\mathrm{C}}$ \\
\hline 38 & $4,7,10,13,16,19-$-Docosahexaenoic acid & n.d. & n.d. & n.d. & n.d. & $2.44 \pm 0.07^{\mathrm{A}}$ & $1.93 \pm 0.06^{\mathrm{B}}$ \\
\hline \multirow[t]{2}{*}{39} & 7,10,13,16,19-Docosapentaenoic acid & n.d. & n.d. & n.d. & n.d. & $2.56 \pm 0.07^{\mathrm{A}}$ & $2.10 \pm 0.05^{\mathrm{B}}$ \\
\hline & Alcohols & $25.49 \pm 0.79^{a}$ & $15.25 \pm 0.15^{b}$ & $13.10 \pm 0.31^{c}$ & $15.33 \pm 0.46^{A}$ & $31.95 \pm 1.65^{B}$ & $27.38 \pm 0.45^{C}$ \\
\hline 2 & Decanol & n.d. & $1.02 \pm 0.01$ & n.d. & n.d. & $1.63 \pm 0.03^{\mathrm{A}}$ & $1.23 \pm 0.01^{\mathrm{B}}$ \\
\hline 4 & Undecanol & $1.62 \pm 0.02^{\mathrm{a}}$ & $1.03 \pm 0.00^{\mathrm{b}}$ & n.d. & $0.82 \pm 0.00^{\mathrm{A}}$ & $1.63 \pm 0.03^{\mathrm{B}}$ & $1.26 \pm 0.04^{\mathrm{C}}$ \\
\hline 7 & Dodecanol & $1.63 \pm 0.02^{\mathrm{a}}$ & $1.02 \pm 0.01^{\mathrm{b}}$ & n.d. & $0.83 \pm 0.00^{\mathrm{A}}$ & n.d. & $1.24 \pm 0.01^{\mathrm{B}}$ \\
\hline 9 & Tridecanol & $1.68 \pm 0.01^{\mathrm{a}}$ & $1.03 \pm 0.00^{\mathrm{b}}$ & $0.98 \pm 0.06^{\mathrm{b}}$ & $0.84 \pm 0.00^{\mathrm{A}}$ & $1.64 \pm 0.02^{\mathrm{B}}$ & $1.28 \pm 0.05^{\mathrm{C}}$ \\
\hline 10 & Tetradecanol & $1.64 \pm 0.02^{\mathrm{a}}$ & $1.03 \pm 0.01^{\mathrm{b}}$ & $0.97 \pm 0.06^{\mathrm{b}}$ & $0.84 \pm 0.00^{\mathrm{A}}$ & $1.65 \pm 0.02^{\mathrm{B}}$ & $1.25 \pm 0.01^{\mathrm{C}}$ \\
\hline 13 & Hexadecanol & $2.17 \pm 0.16^{\mathrm{a}}$ & $1.35 \pm 0.02^{\mathrm{b}}$ & $1.31 \pm 0.02^{\mathrm{b}}$ & $1.65 \pm 0.02^{\mathrm{A}}$ & $2.76 \pm 0.20^{\mathrm{B}}$ & $2.37 \pm 0.10^{\mathrm{C}}$ \\
\hline 21 & Octadece-9-nol & $2.83 \pm 0.23^{\mathrm{a}}$ & $1.67 \pm 0.04^{\mathrm{b}}$ & $1.70 \pm 0.09^{\mathrm{b}}$ & $2.28 \pm 0.01^{\mathrm{A}}$ & $4.02 \pm 0.50^{\mathrm{B}}$ & $3.54 \pm 0.16^{\mathrm{B}}$ \\
\hline 23 & Octadecanol & $2.05 \pm 0.13^{\mathrm{a}}$ & $1.27 \pm 0.03^{\mathrm{b}}$ & $1.26 \pm 0.02^{\mathrm{b}}$ & $1.50 \pm 0.01^{\mathrm{A}}$ & $2.55 \pm 0.20^{\mathrm{B}}$ & $2.06 \pm 0.03^{C}$ \\
\hline 34 & Eicosanol & $1.63 \pm 0.02^{\mathrm{a}}$ & $1.02 \pm 0.01^{\mathrm{b}}$ & $0.97 \pm 0.06^{\mathrm{b}}$ & $0.85 \pm 0.02^{\mathrm{A}}$ & $1.65 \pm 0.03^{\mathrm{B}}$ & $1.24 \pm 0.01^{\mathrm{B}}$ \\
\hline 40 & Docosanol & $1.62 \pm 0.02^{\mathrm{a}}$ & n.d. & n.d. & $0.83 \pm 0.00^{\mathrm{A}}$ & $1.64 \pm 0.02^{\mathrm{B}}$ & $1.23 \pm 0.00^{\mathrm{C}}$ \\
\hline 50 & Hexacosanol & n.d. & n.d. & $0.96 \pm 0.06$ & n.d. & n.d. & n.d. \\
\hline 52 & Octacosanol & $1.73 \pm 0.05^{\mathrm{a}}$ & $1.08 \pm 0.02^{\mathrm{b}}$ & $1.05 \pm 0.04^{\mathrm{b}}$ & $0.99 \pm 0.01^{\mathrm{A}}$ & $1.82 \pm 0.09^{\mathrm{B}}$ & $1.40 \pm 0.03^{\mathrm{C}}$ \\
\hline 58 & Octacosane-1,3-diol & $1.64 \pm 0.03^{\mathrm{a}}$ & $1.02 \pm 0.01^{\mathrm{b}}$ & $0.98 \pm 0.05^{\mathrm{b}}$ & $0.86 \pm 0.01^{\mathrm{A}}$ & $1.69 \pm 0.04^{\mathrm{B}}$ & $1.26 \pm 0.01^{\mathrm{C}}$ \\
\hline 59 & Triacontanol & $1.68 \pm 0.04^{\mathrm{a}}$ & $1.04 \pm 0.02^{\mathrm{b}}$ & $1.00 \pm 0.05^{\mathrm{b}}$ & $0.94 \pm 0.01^{\mathrm{A}}$ & $1.76 \pm 0.06^{\mathrm{B}}$ & $1.33 \pm 0.02^{\mathrm{C}}$ \\
\hline 61 & Dotriacontanol & $1.63 \pm 0.02^{\mathrm{a}}$ & n.d. & n.d. & $0.83 \pm 0.01^{\mathrm{A}}$ & $1.66 \pm 0.03^{\mathrm{B}}$ & $1.24 \pm 0.02^{\mathrm{C}}$ \\
\hline \multirow[t]{2}{*}{24} & 3,7,11,15-Tetramethyl-2-hexadecen-1-ol & $1.92 \pm 0.04^{\mathrm{a}}$ & $1.67 \pm 0.04^{\mathrm{b}}$ & $1.91 \pm 0.01^{\mathrm{a}}$ & $1.48 \pm 0.15^{\mathrm{A}}$ & $5.86 \pm 0.38^{\mathrm{B}}$ & $5.46 \pm 0.02^{\mathrm{B}}$ \\
\hline & Sterols & $1.10 \pm 0.07^{a}$ & $1.19 \pm 0.08^{a}$ & $1.07 \pm 0.08^{a}$ & $1.18 \pm 0.04^{A}$ & $2.54 \pm 0.21^{B}$ & $2.71 \pm 0.24^{B}$ \\
\hline 53 & $24 \beta$-Methylcholesta-5,22E-dien-3 $\beta$-ol & n.d. & n.d. & n.d. & $0.32 \pm 0.01^{\mathrm{A}}$ & $1.40 \pm 0.10^{\mathrm{B}}$ & $1.50 \pm 0.06^{\mathrm{B}}$ \\
\hline 54 & 24-Methylcholesta-5,24(28)-dien-3 $\beta$-ol & n.d. & $0.19 \pm 0.00 \mathrm{a}$ & $0.19 \pm 0.01^{\mathrm{a}}$ & n.d. & n.d. & n.d. \\
\hline 55 & $24 \alpha$-Methylcholest-5-en-3 $\beta$-ol & $0.30 \pm 0.01^{\mathrm{a}}$ & $0.21 \pm 0.01^{\mathrm{b}}$ & $0.23 \pm 0.00^{\mathrm{b}}$ & $0.18 \pm 0.01^{\mathrm{A}}$ & $0.33 \pm 0.01^{\mathrm{B}}$ & $0.26 \pm 0.02^{\mathrm{C}}$ \\
\hline 57 & $24 \alpha$-Ethylcholest-5-en-3 $\beta$-ol & $0.80 \pm 0.06^{\mathrm{a}}$ & $0.63 \pm 0.06^{\mathrm{b}}$ & $0.66 \pm 0.09^{\mathrm{ab}}$ & $0.50 \pm 0.02^{\mathrm{A}}$ & $0.81 \pm 0.11^{\mathrm{B}}$ & $0.77 \pm 0.10^{\mathrm{B}}$ \\
\hline \multirow[t]{2}{*}{64} & Unidentified Sterol & n.d. & $0.16 \pm 0.00^{\mathrm{b}}$ & n.d. & $0.18 \pm 0.01^{\mathrm{A}}$ & $0.30 \pm 0.01^{\mathrm{A}}$ & $0.23 \pm 0.01^{\mathrm{A}}$ \\
\hline & Monoglycerides & $0.10 \pm 0.01^{a}$ & $0.05 \pm 0.01^{b}$ & $0.06 \pm 0.01^{b}$ & $0.18 \pm 0.01^{A}$ & $0.62 \pm 0.11^{B}$ & $0.67 \pm 0.02 B$ \\
\hline 31 & 2,3-Dihydroxypropyl dodecanoate & $0.02 \pm 0.00^{\mathrm{a}}$ & $0.01 \pm 0.00^{\mathrm{b}}$ & n.d. & $0.05 \pm 0.00^{\mathrm{A}}$ & $0.06 \pm 0.02^{\mathrm{A}}$ & $0.05 \pm 0.01^{\mathrm{A}}$ \\
\hline 37 & 3-Hexadecoxypropane-1,2-diol & n.d. & n.d. & n.d. & $0.03 \pm 0.01^{\mathrm{A}}$ & $0.26 \pm 0.05^{\mathrm{B}}$ & $0.25 \pm 0.01^{\mathrm{B}}$ \\
\hline 41 & 1,3-Dihydroxy-2-propanyl palmitate & n.d. & n.d. & $0.01 \pm 0.00$ & n.d. & n.d. & n.d. \\
\hline 42 & 2,3-Dihydroxypropyl palmitate & $0.01 \pm 0.00$ & n.d. & n.d. & $0.04 \pm 0.00^{\mathrm{A}}$ & n.d. & $0.05 \pm 0.01^{\mathrm{A}}$ \\
\hline 44 & 3-Octadecoxypropane-1,2-diol & $0.01 \pm 0.00^{\mathrm{a}}$ & $0.01 \pm 0.00^{\mathrm{b}}$ & n.d. & $0.06 \pm 0.00^{\mathrm{A}}$ & $0.30 \pm 0.05^{\mathrm{B}}$ & $0.33 \pm 0.01^{\mathrm{B}}$ \\
\hline 46 & 1,3-Dihydroxy-2-propanyl stearate & $0.03 \pm 0.00^{\mathrm{a}}$ & n.d. & n.d. & n.d. & n.d. & n.d. \\
\hline 47 & 2,3-Dihydroxypropyl oleate & $0.02 \pm 0.00^{\mathrm{a}}$ & $0.03 \pm 0.01^{\mathrm{a}}$ & $0.03 \pm 0.01^{\mathrm{a}}$ & n.d. & n.d. & n.d. \\
\hline 48 & 2,3-Dihydroxypropyl stearate & n.d. & $\operatorname{tr}^{\mathrm{a}}$ & $0.01 \pm 0.00^{\mathrm{b}}$ & n.d. & n.d. & n.d. \\
\hline & Others & n.d. & $0.04 \pm 0.00^{a}$ & $0.03 \pm 0.00^{a}$ & $0.09 \pm 0.00^{A}$ & $0.15 \pm 0.15^{A B}$ & $0.36 \pm 0.11^{B}$ \\
\hline 5 & 2,6-bis(1,1-Dimethylethyl)phenol & n.d. & $0.03 \pm 0.00^{\mathrm{a}}$ & $0.02 \pm 0.00^{\mathrm{b}}$ & $0.09 \pm 0.00^{\mathrm{A}}$ & $0.15 \pm 0.15^{\mathrm{AB}}$ & $0.36 \pm 0.11^{\mathrm{B}}$ \\
\hline 51 & $\alpha$-Tocopherol & n.d. & $0.01 \pm 0.00^{\mathrm{a}}$ & $0.01 \pm 0.00^{\mathrm{a}}$ & n.d. & n.d. & n.d. \\
\hline & Total & $74.69 \pm 2.92^{a}$ & $58.94 \pm 3.83^{b}$ & $54.30 \pm 1.46^{b}$ & $42.65 \pm 2.32^{A}$ & $121.40 \pm 6.39^{B}$ & $99.78 \pm 5.43^{C}$ \\
\hline
\end{tabular}

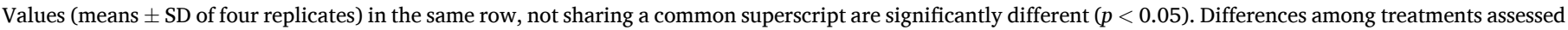

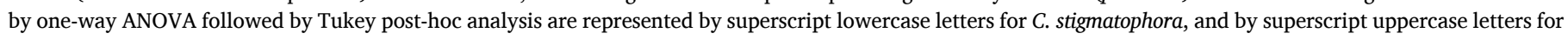


H. cf. andersenii. All the compounds containing hydroxyl and/or carboxyl groups are identified as the correspondent trimethylsilyl (TMS) derivatives. ${ }^{1}$ Contains cis and trans isomers. n.d. - non detected.

a)

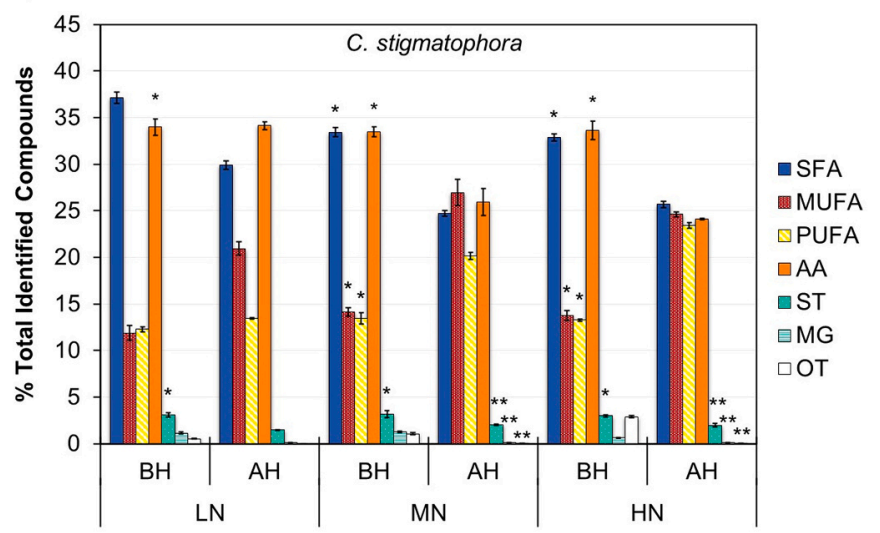

b)

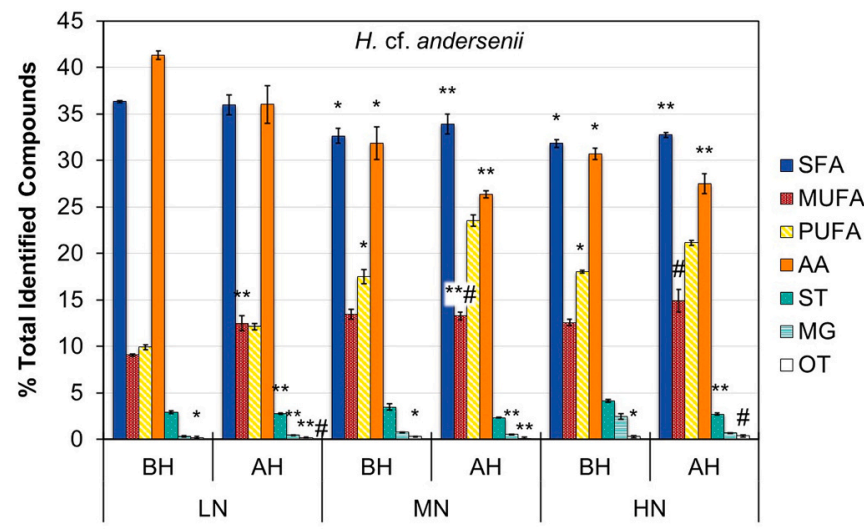

Fig. 2. Changes in main lipophilic classes before (BH) and after $(\mathrm{AH})$ alkaline hydrolysis in a) Chlorella stigmatophora and b) Hemiselmis cf. andersenii grown under low (LN), medium (MN) and high (HN) nitrogen experimental conditions. Values are expressed as mean \pm standard deviation, $n=4$ replicates. Values from the same lipid class sharing common symbols (* before hydrolysis, and $* *$ or \# after hydrolysis) are not significantly different $(p>0.05)$ among treatments. SFA — saturated fatty acids; MUFA — monounsaturated fatty acids; PUFA — polyunsaturated fatty acids; AA — aliphatic alcohols; ST — sterols; MG — monoglycerides; OT — other compounds.

microalgae but also the processing strategies to be used by the industry. For instance, non-esterified fatty acids in fish oils are more efficiently absorbed by humans than their esterified form (triacylglycerol, and ethyl esters) [60].

\subsection{Multivariate analysis of lipid profile}

Hierarchical cluster analysis (HCA) of microalgal lipid extracts before hydrolysis (Fig. 4a) did not reflect the classification of $H$. cf. andersenii cultured under different nitrogen supplementations. Instead, $H$. cf. andersenii grown in LN conditions (HLN) was farthest positioned, in a different clade closest to $C$. stigmatophora group. This discrimination was promoted by the greater abundance of MUFA, PUFA, C16:0, and phytol observed for $H$. cf. andersenii grown in MN (HMN) and HN (HHN) conditions. Moreover, the similarity of $H$. cf. andersenii cultured under LN conditions with $C$. stigmatophora samples was related with low values of very-long chain PUFA (EPA, DHA) and high amounts of SFA, which were common features of these samples.

After hydrolysis (Fig. 4b), it is noteworthy that $H$. cf. andersenii cultured under different nitrogen supplementations are within the same a)

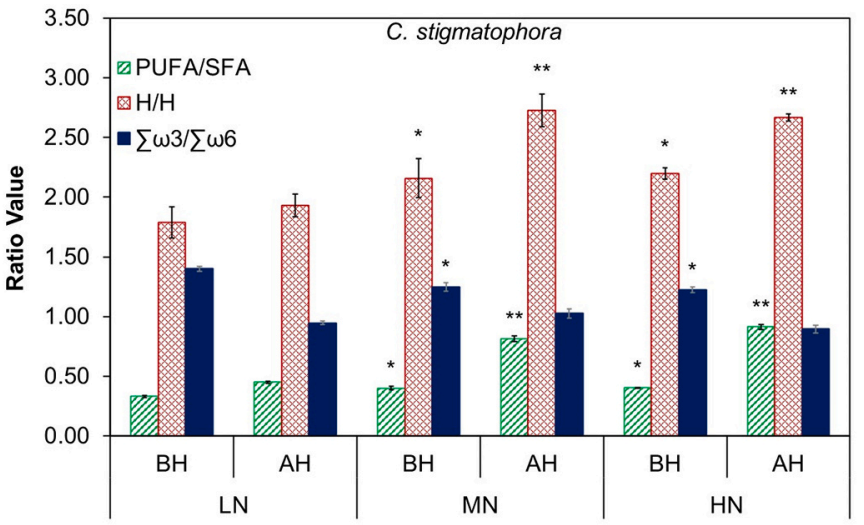

b)

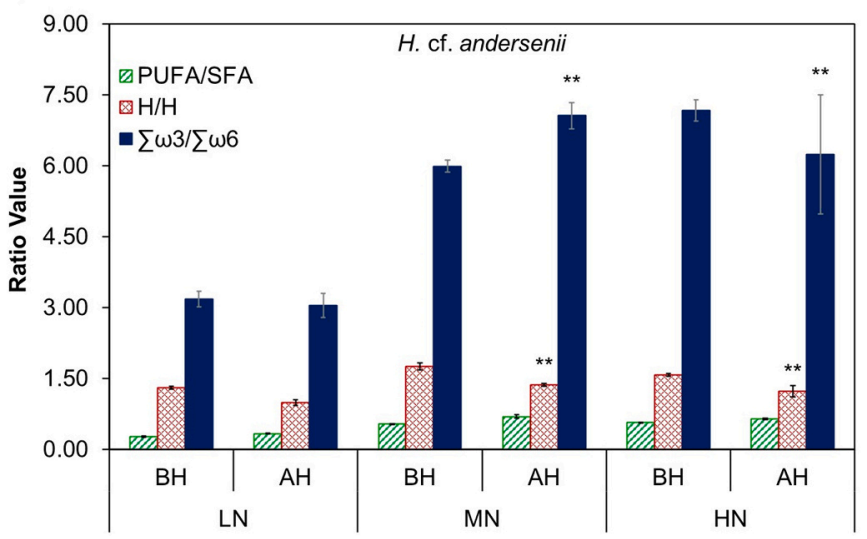

Fig. 3. Variations in a) Chlorella stigmatophora and b) Hemiselmis cf. andersenii nutritional values in response to nitrogen-induced changes, $n=4$ replicates. Values from the same nutritional ratio sharing common symbols (* before hydrolysis, and $* *$ after hydrolysis) are not significantly different $(p>0.05)$ among treatments. $\mathrm{H} / \mathrm{H}$ - hypocholesterolaemic/hypercholesterolaemic fatty acids ratio; PUFA/SFA - polyunsaturated to saturated fatty acids ratio; LN low nitrogen supplementation; $\mathrm{MN}$ - medium nitrogen supplementation; $\mathrm{HN}$ - high nitrogen supplementation; $\mathrm{BH}$ - before hydrolysis; $\mathrm{AH}$ after hydrolysis.

cluster, despite having a distinction among HLN and the other $H$. cf. andersenii samples (medium nitrogen - HMN; and high nitrogen $\mathrm{HHN}$ ). These observations show once more that $H$. cf. andersenii grown in HMN and HHN are chemically more similar than HLN. Conversely, C. stigmatophora grown in different nitrogen supplementations (low CLN; medium - CMN; high - CHN) did not cluster together, with CLN presenting the most distinct metabolic features.

\section{Conclusions}

Chlorella stigmatophora and Hemiselmis cf. andersenii growth patterns and nitrogen uptake dynamics suggests that nitrogen was not the growth limiting nutrient under high nitrogen supplementation. Gas chromatography-mass spectrometry untargeted analysis allowed the study of the lipid remodelling of both microalgae in response to nitrogen-induced changes. Microalgae grown under medium and high nitrogen supplementation showed potential for high-value compound exploitation. For instance, glycosyl sterols, suitable to be applied in food and pharmaceutical fields, were only found for C. stigmatophora at medium and high nitrogen supplementation, whilst the highest contents of $\omega 3$ and 
a) Before hydrolysis

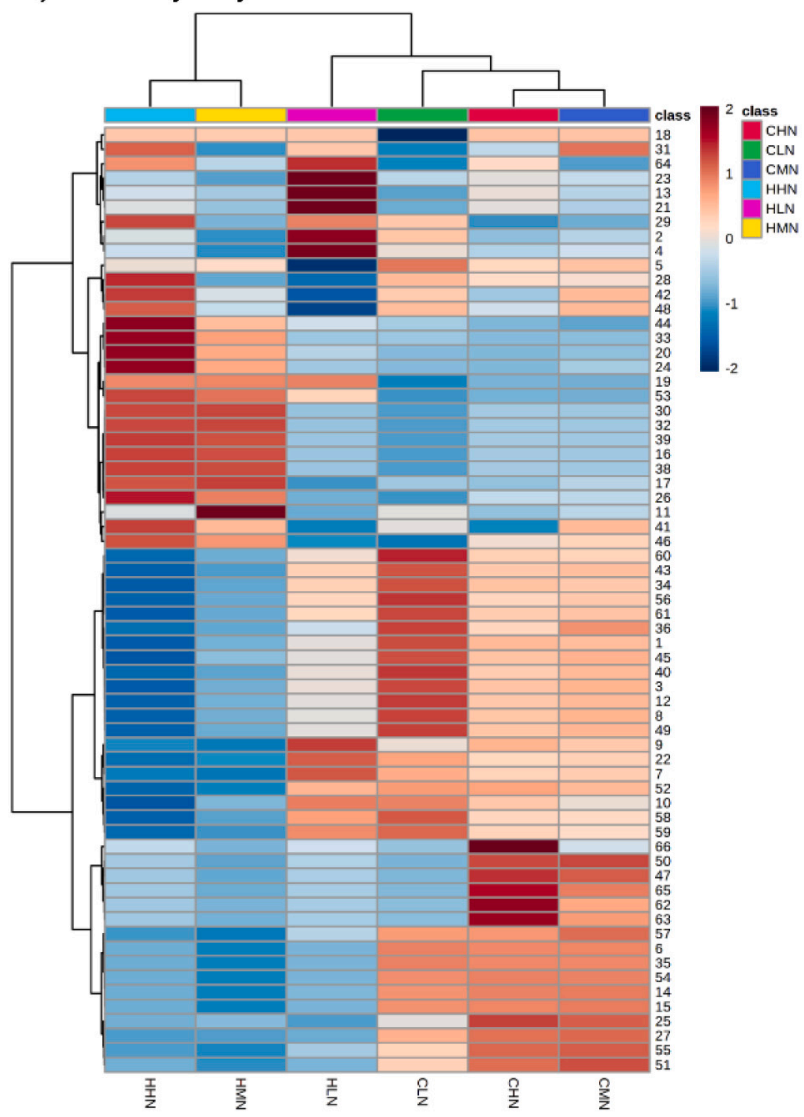

b) After hydrolysis

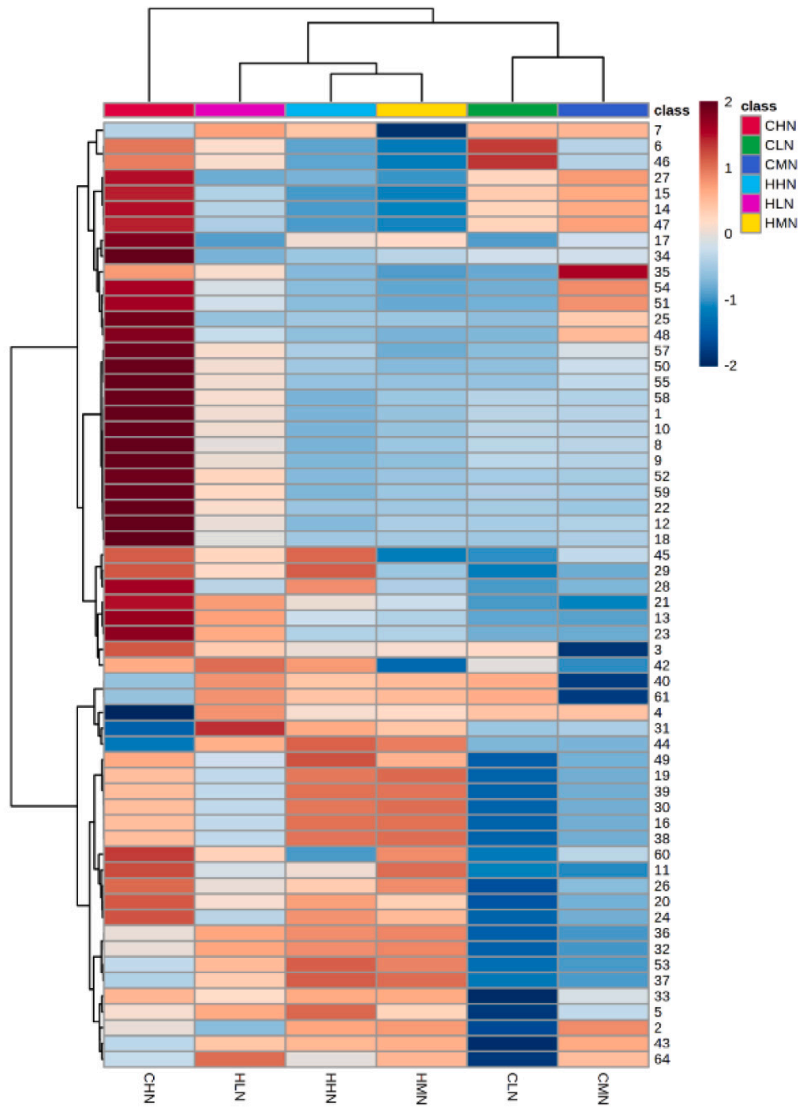

Fig. 4. Hierarchical clustering analysis heat maps based on Euclidean clustering distance and the ward clustering method, $n=4$ replicates, for Chlorella stigmatophora and Hemiselmis cf. andersenii grown under different nitrogen supplementations a) before and b) after alkaline hydrolysis. Feature descriptions can be seen in Table 2 and 3. The heat maps reflect the relative levels of metabolites among different treatment groups, the color scheme is associated with the elevation and reduction in metabolite level through treatments: dark blue, lowest; dark red, highest. HLN, HMN, and HHN stands for $H$. cf. andersenii grown under low, medium, and high nitrogen supplementations, respectively. CLN, CMN, CHN stands for C. stigmatophora grown in low, medium, and high nitrogen supplementations, respectively. (For interpretation of the references to color in this figure legend, the reader is referred to the web version of this article.)

polyunsaturated fatty acids were found for $H$. cf. andersenii under these conditions. The analysis of chlorophyll and phytol contents show that phytol is a good indicator for the chlorophyll content of $H$. cf. andersenii but not for that of $C$. stigmatophora. The diverse ways by which both microalgae modulated their elemental stoichiometry and lipid content in response to the same perturbation highlighted the influence of phylogeny on the carbon flux, through metabolic networks and accumulation. However, either the use of enzyme inhibitors or genetic manipulation would be necessary to demonstrate the specific changes in metabolism.

Supplementary data to this article can be found online at https://doi. org/10.1016/j.algal.2021.102417.

\section{Statement of informed consent, human/animal rights}

No conflicts, informed consent, human or animal rights applicable.

\section{CRediT authorship contribution statement}

Tomásia Fernandes: Conceptualization, Methodology, Investigation, Formal analysis, Data curation, Writing - original draft, Validation. Artur Ferreira: Formal analysis, Project administration, Funding acquisition, Supervision, Writing - review \& editing, Validation. Nereida Cordeiro: Conceptualization, Methodology, Project administration, Funding acquisition, Supervision, Writing - review \& editing, Validation.

\section{Declaration of competing interest}

The authors declare the following financial interests/personal relationships which may be considered as potential competing interests: Nereida Cordeiro reports financial support was provided by Foundation for Science and Technology. Nereida Cordeiro reports financial support was provided by European Territorial Cooperation Programme PCTMAC 2014-2020. Tomasia Fernandes reports financial support was provided by Regional Agency for Development of Research, Technology and Innovation of Madeira.

\section{Acknowledgments}

This research was partially supported by Portuguese funds through FCT - Foundation for Science and Technology within the scope of UIDB/ 04423/2020 and UIDP/04423/2020 and the European Territorial Cooperation Programme PCT-MAC 2014-2020 through project REBECA-CCT (MAC/1.1.B/269). Tomásia Fernandes was financially supported by a doctoral grant from ARDITI (Regional Agency for Development of Research, Technology and Innovation of Madeira, Portugal), Project M1420-09-5369-FSE-000002.

\section{References}

[1] M. Bhattacharya, S. Goswami, Microalgae - a green multi-product biorefinery for future industrial prospects, Biocatal. Agric. Biotechnol. 25 (2020), https://doi.org/ 10.1016/j.bcab.2020.101580. 
[2] H. Traugott, M. Zollmann, H. Cohen, A. Chemodanov, A. Liberzon, A. Golberg, Aeration and nitrogen modulated growth rate and chemical composition of green macroalgae Ulva sp. cultured in a photobioreactor, Algal Res. 47 (2020), 101808, https://doi.org/10.1016/j.algal.2020.101808.

[3] K. Srirangan, M.E. Pyne, C. Perry Chou, Biochemical and genetic engineering strategies to enhance hydrogen production in photosynthetic algae and cyanobacteria, Bioresour. Technol. 102 (2011) 8589-8604, https://doi.org/ 10.1016/j.biortech.2011.03.087.

[4] A.F. Talebi, M. Tohidfar, S.M. Mousavi Derazmahalleh, A. Sulaiman, A. S. Baharuddin, M. Tabatabaei, Biochemical modulation of lipid pathway in microalgae Dunaliella sp. for biodiesel production, Biomed Res. Int. 2015 (2015), https://doi.org/10.1155/2015/597198.

[5] V.O. Adesanya, M.P. Davey, S.A. Scott, A.G. Smith, Kinetic modelling of growth and storage molecule production in microalgae under mixotrophic and autotrophic conditions, Bioresour. Technol. 157 (2014) 293-304, https://doi.org/10.1016/j. biortech.2014.01.032.

[6] S.P. Slocombe, Q. Zhang, M. Ross, A. Anderson, N.J. Thomas, Á. Lapresa, C. RadMenéndez, C.N. Campbell, K.D. Black, M.S. Stanley, J.G. Day, Unlocking nature's treasure-chest: screening for oleaginous algae, Sci. Rep. 5 (2015) 1-17, https://doi org/10.1038/srep09844.

[7] M.T.T. Vu, C. Douëtte, T.A. Rayner, C. Thoisen, S.L. Nielsen, B.W. Hansen, Optimization of photosynthesis, growth, and biochemical composition of the microalga Rhodomonas salina - an established diet for live feed copepods in aquaculture, J. Appl. Phycol. 28 (2016) 1485-1500, https://doi.org/10.1007/ s10811-015-0722-2.

[8] T. Fernandes, A. Martel, N. Cordeiro, Exploring Pavlova pinguis chemical diversity: a potentially novel source of high value compounds, Sci. Rep. 10 (2020) 1-11, https://doi.org/10.1038/s41598-019-57188-y.

[9] P. Hidalgo, G. Ciudad, R. Navia, Evaluation of different solvent mixtures in esterifiable lipids extraction from microalgae Botryococcus braunii for biodiesel production, Bioresour. Technol. 201 (2016) 360-364, https://doi.org/10.1016/j. biortech.2015.11.031.

[10] X. Wang, H.K. Fosse, K. Li, M.S. Chauton, O. Vadstein, K.I. Reitan, Influence of nitrogen limitation on lipid accumulation and EPA and DHA content in four marine microalgae for possible use in aquafeed, Front. Mar. Sci. 6 (2019) 1-10, https:// doi.org/10.3389/fmars.2019.00095.

[11] S. Willette, S.S. Gill, B. Dungan, T.M. Schaub, J.M. Jarvis, R.St. Hilaire, F. Omar Holguin, Alterations in lipidome and metabolome profiles of Nannochloropsis salina in response to reduced culture temperature during sinusoidal temperature and light, Algal Res. 32 (2018) 79-92, https://doi.org/ 10.1016/j.algal.2018.03.001.

[12] M. Le Chevanton, M. Garnier, E. Lukomska, N. Schreiber, J.P. Cadoret, B. SaintJean, G. Bougaran, Effects of nitrogen limitation on Dunaliella sp.-Alteromonas sp. interactions: from mutualistic to competitive relationships, Front. Mar. Sci. 3 (2016) 1-11, https://doi.org/10.3389/fmars.2016.00123.

[13] M. Giordano, J.A. Raven, Nitrogen and sulfur assimilation in plants and algae, Aquat. Bot. 118 (2014) 45-61, https://doi.org/10.1016/j.aquabot.2014.06.012.

[14] C. Ratledge, Z. Cohen, Microbial and algal oils: do they have a future for biodiesel or as commodity oils? Lipid Technol. 20 (2008) 155-160, https://doi.org/ 10.1002/lite.200800044.

[15] L. Barsanti, P. Gualtieri, Summaries of the ten algal divisions, in: L. Barsanti, P. Gualtieri (Eds.), Algae Anatomy, Biochem. Biotechnol., CRC Press Taylor \& Francis, Boca Raton, 2006, pp. 1-35.

[16] M. Abidizadegan, E. Peltomaa, J. Blomster, The potential of cryptophyte algae in biomedical and pharmaceutical applications, Front. Pharmacol. 11 (2021) 1-17, https://doi.org/10.3389/fphar.2020.618836.

[17] E. Peltomaa, M.D. Johnson, S.J. Taipale, Marine cryptophytes are great sources of EPA and DHA, Mar. Drugs 16 (2018) 1-11, https://doi.org/10.3390/md16010003.

[18] G.A. Dunstan, M.R. Brown, J.K. Volkman, Cryptophyceae and rhodophyceae; chemotaxonomy, phylogeny, and application, Phytochemistry. 66 (2005) 2557-2570, https://doi.org/10.1016/j.phytochem.2005.08.015.

[19] T. Fernandes, N. Cordeiro, Hemiselmis andersenii and Chlorella stigmatophora as new sources of high-value compounds: a lipidomic approach, J. Phycol. 56 (2020) 1493-1504, https://doi.org/10.1111/jpy.13042.

[20] E.K. Matich, M. Ghafari, E. Camgoz, E. Caliskan, B.A. Pfeifer, B.Z. Haznedaroglu, G. E. Atilla-Gokcumen, Time-series lipidomic analysis of the oleaginous green microalga species Ettlia oleoabundans under nutrient stress, Biotechnol. Biofuels. 11 (2018) 1-15, https://doi.org/10.1186/s13068-018-1026-y.

[21] S.M. Tibbetts, J. Mann, A. Dumas, Apparent digestibility of nutrients, energy, essential amino acids and fatty acids of juvenile Atlantic salmon (Salmo salar L.) diets containing whole-cell or cell-ruptured Chlorella vulgaris meals at five dietary inclusion levels, Aquaculture. 481 (2017) 25-39, https://doi.org/10.1016/j. aquaculture.2017.08.018.

[22] J.N. Rosenberg, N. Kobayashi, A. Barnes, E.A. Noel, M.J. Betenbaugh, G.A. Oyler, Comparative analyses of three Chlorella species in response to light and sugar reveal distinctive lipid accumulation patterns in the microalga $C$. sorokiniana, PLoS One. 9 (2014), https://doi.org/10.1371/journal.pone.0092460.

[23] P. Ranadheer, R. Kona, R.V. Sreeharsha, S. Venkata Mohan, Non-lethal nitrate supplementation enhances photosystem II efficiency in mixotrophic microalgae towards the synthesis of proteins and lipids, Bioresour. Technol. 283 (2019) 373-377, https://doi.org/10.1016/j.biortech.2019.03.089.

[24] R.R. Guillard, J.H. Ryther, Studies of marine planktonic diatoms. I. Cyclotella nana Hustedt, and Detonula confervacea (cleve) Gran, Can. J. Microbiol. 8 (1962) 229-239, https://doi.org/10.1139/m62-029.
[25] R.R.L. Guillard, Culture of phytoplankton for feeding marine invertebrates, in: W. L. Smith, M.H. Chanley (Eds.), Cult. Mar. Invertebr. Anim, Springer, Boston, 1975, pp. 29-60, https://doi.org/10.1007/978-1-4615-8714-9_3.

[26] H. Safafar, S. Langvad, P. Møller, C. Jacobsen, Storage conditions affect oxidative stability and nutritional composition of freeze-dried Nannochloropsis salina, Eur. J. Lipid Sci. Technol. 119 (2017) 1-10, https://doi.org/10.1002/ejlt.201600477.

[27] L. Xin, H. Hong-ying, G. Ke, S. Ying-xue, Effects of different nitrogen and phosphorus concentrations on the growth, nutrient uptake, and lipid accumulation of a freshwater microalga Scenedesmus sp. Bioresour. Technol. 101 (2010) 5494-5500, https://doi.org/10.1016/j.biortech.2010.02.016.

[28] C. Wan, F.W. Bai, X.Q. Zhao, Effects of nitrogen concentration and media replacement on cell growth and lipid production of oleaginous marine microalga Nannochloropsis oceanica DUT01, Biochem. Eng. J. 78 (2013) 32-38, https://doi. org/10.1016/j.bej.2013.04.014.

[29] Y. Chen, S. Vaidyanathan, Simultaneous assay of pigments, carbohydrates, proteins and lipids in microalgae, Anal. Chim. Acta 776 (2013) 31-40, https://doi.org/ 10.1016/j.aca.2013.03.005.

[30] S.W. Jeffrey, G.F. Humphrey, New spectrophotometric equations for determining chlorophylls a, b, c1 and c2 in higher plants, algae and natural phytoplankton, Biochem. Physiol. Pflanz. 167 (1975) 191-194, https://doi.org/10.1016/s00153796(17)30778-3.

[31] E.G. Bligh, W.J. Dyer, A rapid method of total lipid extraction and purification, Can. J. Biochem. Phys. 37 (1959) 911-917, https://doi.org/10.1139/o59-099.

[32] T. Fernandes, I. Fernandes, C.A.P. Andrade, N. Cordeiro, Marine microalgae growth and carbon partitioning as a function of nutrient availability, Bioresour. Technol. 214 (2016) 541-547, https://doi.org/10.1016/j.biortech.2016.05.001.

[33] S.A.O. Santos, C. Vilela, C.S.R. Freire, M.H. Abreu, S.M. Rocha, A.J.D. Silvestre, Chlorophyta and Rhodophyta macroalgae: a source of health promoting phytochemicals, Food Chem. 183 (2015) 122-128, https://doi.org/10.1016/j. foodchem.2015.03.006.

[34] L. Nyström, A. Schär, A.M. Lampi, Steryl glycosides and acylated steryl glycosides in plant foods reflect unique sterol patterns, Eur. J. Lipid Sci. Technol. 114 (2012) 656-669, https://doi.org/10.1002/ejlt.201200033.

[35] J.J. Myher, L. Marai, A. Kuksis, Identification of monoacyl and monoalkylglycerols by gas liquid chromatography mass spectrometry using polar siloxane liquid phases, J. Lipid Res. 15 (1974) 586-592, https://doi.org/10.1016/s0022-2275(20) 36760-2.

[36] B. Xu, L. Zhang, F. Ma, W. Zhang, X. Wang, Q. Zhang, D. Luo, H. Ma, P. Li, Determination of free steroidal compounds in vegetable oils by comprehensive two-dimensional gas chromatography coupled to time-of-flight mass spectrometry, Food Chem. 245 (2018) 415-425, https://doi.org/10.1016/j. foodchem.2017.10.114.

[37] S. Takatsuto, K. Omote, Phytosterol composition in the pollen of sunflower, Helianthus annuus L, Agric. Biol. Chem. 53 (1989) 3363-3364, https://doi.org/ 10.1080/00021369.1989.10869818.

[38] J. Santos-Silva, R.J.B. Bessa, F. Santos-Silva, Effect of genotype, feeding system and slaughter weight on the quality of light lambs. II. Fatty acid composition of meat, Livest. Prod. Sci. 77 (2002) 187-194, https://doi.org/10.1016/S0301-6226(02) 00059-3.

[39] J. Xia, D.S. Wishart, Using MetaboAnalyst 3.0 for comprehensive metabolomics data analysis, Curr. Protoc. Bioinform 55 (2016) 14.10.1-14.10.91, https://doi. org/10.1002/cpbi.11.

[40] E. Lee, M. Jalalizadeh, Q. Zhang, Growth kinetic models for microalgae cultivation: a review, Algal Res. 12 (2015) 497-512, https://doi.org/10.1016/j. algal.2015.10.004.

[41] Y. Lee, W. Chen, H. Shen, D. Han, Y. Li, H.D.T. Jones, J.A. Timlin, Q. Hu, Basic culturing and analytical measurement techniques, in: A. Richmond, Q. Hu (Eds.), Handb. Microalgal Cult. Appl. Phycol. Biotechnol, Second ed., John Wiley \& Sons, 2013, pp. 37-68.

[42] I.D. Adamakis, P.A. Lazaridis, E. Terzopoulou, S. Torofias, M. Valari, P. Kalaitzi, V. Rousonikolos, D. Gkoutzikostas, A. Zouboulis, G. Zalidis, K.S. Triantafyllidis, Cultivation, characterization, and properties of Chlorella vulgaris microalgae with different lipid contents and effect on fast pyrolysis oil composition, environ, Sci. Pollut. Res. 25 (2018) 23018-23032, https://doi.org/10.1007/s11356-018-23685 .

[43] A. Beuckels, E. Smolders, K. Muylaert, Nitrogen availability influences phosphorus removal in microalgae-based wastewater treatment, Water Res. 77 (2015) 98-106, https://doi.org/10.1016/j.watres.2015.03.018.

[44] J. Fan, Y. Cui, M. Wan, W. Wang, Y. Li, Lipid accumulation and biosynthesis genes response of the oleaginous Chlorella pyrenoidosa under three nutrition stressors, Biotechnol. Biofuels. 7 (2014) 1-14, https://doi.org/10.1186/1754-6834-7-17.

[45] M. Hildebrand, R.M. Abbriano, J.E.W. Polle, J.C. Traller, E.M. Trentacoste, S. R. Smith, A.K. Davis, Metabolic and cellular organization in evolutionarily diverse microalgae as related to biofuels production, Curr. Opin. Chem. Biol. 17 (2013) 506-514, https://doi.org/10.1016/j.cbpa.2013.02.027.

[46] I. Gifuni, A. Pollio, C. Safi, A. Marzocchella, G. Olivieri, Current bottlenecks and challenges of the microalgal biorefinery, Trends Biotechnol. 37 (2019) 242-252, https://doi.org/10.1016/j.tibtech.2018.09.006.

[47] C.C.C.R. De Carvalho, M.J. Caramujo, The various roles of fatty acids, Molecules. 23 (2018), https://doi.org/10.3390/molecules23102583.

[48] T. Fernandes, I. Fernandes, C.A.P. Andrade, N. Cordeiro, Changes in Fatty Acid Biosynthesis in Marine Microalgae as a Response to Medium Nutrient Availability, Algal Res. (2016) 314-320, https://doi.org/10.1016/j.algal.2016.07.005.

[49] E. Da Costa, J. Silva, S.H. Mendonça, M.H. Abreu, M.R. Domingues, Lipidomic approaches towards deciphering glycolipids from microalgae as a reservoir of bioactive lipids, Mar. Drugs. 14 (2016), https://doi.org/10.3390/md14050101. 
[50] I. Guschina, J. Harwood, Algal lipids and effect of the environment on their biochemistry, in: M.T. Arts, M.T. Brett, M. Kainz (Eds.), Lipids Aquat. Ecosyst, Springer, New York, 2009, pp. 1-24.

[51] S.M. Mudge, Fatty alcohols - a review of their natural synthesis and environmental distribution, Soap Deterg. Assoc. https://www.aciscience.org/docs/ Fatty_Alcohols_Mudge_2005.pdf, 2005.

[52] D. Klaveness, Biology and ecology of the Cryptophyceae: status and challenges, Biol. Oceanogr. 6 (1988) 257-270, https://doi.org/10.1080/ 01965581.1988 .10749530$.

[53] L. Yao, J.A. Gerde, S.L. Lee, T. Wang, K.A. Harrata, Microalgae lipid characterization, J. Agric. Food Chem. 63 (2015) 1773-1787, https://doi.org/ 10.1021/jf5050603.

[54] J. de Moraes, R.N. de Oliveira, J.P. Costa, A.L.G. Junior, D.P. de Sousa, R. M. Freitas, S.M. Allegretti, P.L.S. Pinto, Phytol, a diterpene alcohol from chlorophyll, as a drug against neglected tropical disease schistosomiasis mansoni, PLoS Negl. Trop. Dis. 8 (2014) 51, https://doi.org/10.1371/journal.pntd.0002617.

[55] K. Zienkiewicz, Z.Y. Du, W. Ma, K. Vollheyde, C. Benning, Stress-induced neutral lipid biosynthesis in microalgae - molecular, cellular and physiological insights, Biochim. Biophys. Acta Mol. Cell Biol. Lipids. 1861 (2016) 1269-1281, https://doi org/10.1016/j.bbalip.2016.02.008.
[56] S. Yu, Y. Zhang, Y. Ran, W. Lai, Z. Ran, J. Xu, C. Zhou, X. Yan, Characterization of steryl glycosides in marine microalgae by gas chromatography-triple quadrupole mass spectrometry (GC-QQQ-MS), J. Sci. Food Agric. 98 (2018) 1574-1583, https://doi.org/10.1002/jsfa.8629.

[57] N.G. Mohammady, Total, free and conjugated sterolic forms in three microalgae used in mariculture, Zeitschr. Nat. Sect. C J. Biosci. 59 (2004) 619-624, https:// doi.org/10.1515/znc-2004-9-1002.

[58] B. Véron, J.C. Dauguet, C. Billard, Sterolic biomarkers in marine phytoplankton. II. Free and conjugated sterols of seven species used in mariculture, J. Phycol. 34 (1998) 273-279, https://doi.org/10.1046/j.1529-8817.1998.340273.x.

[59] U.N. Das, Essential fatty acids: biochemistry, physiology and pathology, Biotechnol. J. 1 (2006) 420-439, https://doi.org/10.1002/biot.200600012.

[60] L.D. Lawson, B.G. Hughes, Human absorption of fish oil fatty acids as triacylglycerols, free fatty acids, or ethyl esters, Biochem. Biophys. Res. Commun. 152 (1988) 328-335, https://doi.org/10.1016/S0006-291X(88)80718-6.

[61] L. Paiva, E. Lima, A.I. Neto, M. Marcone, J. Baptista, Health-promoting ingredients from four selected Azorean macroalgae, Food Res. Int. 89 (2016) 432-438, https:// doi.org/10.1016/j.foodres.2016.08.007. 